\title{
Fossil clitellate annelid cocoons and their microbiological inclusions from the Eocene of Seymour Island, Antarctica
}

\author{
Stephen McLoughlin, Benjamin Bomfleur, Thomas Mörs, and Marcelo Reguero
}

\begin{abstract}
Clitellate annelids have a meagre body fossil record but they secrete proteinaceous cocoons for the protection of eggs that, after hardening, are readily fossilized and offer a largely untapped resource for assessing the evolutionary history of this group. We describe three species of clitellate cocoons (viz., Burejospermum seymourense sp. nov., B. punctatum sp. nov. and Pegmatothylakos manumii gen. et sp. nov.) from the lower Eocene La Meseta Formation, Seymour Island, Antarctica. The cocoons probably derive from continental settings and were transported to, and preserved within, nearshore marine to estuarine environments. The cocoons provide the first evidence of commensal or parasitic relationships in the Eocene continental ecosystems of Antarctica. Moreover, numerous micro-organisms and the oldest fossilized examples of animal spermatozoa are preserved as moulds within the consolidated walls of the cocoons. Fossil annelid cocoons offer potential for enhanced palaeoenvironmental interpretation of sediments, correlation between continental and shallowmarine strata, and improved understanding of the development of clitellate annelid reproductive traits and the evolutionary history of soft-bodied micro-organisms in general.
\end{abstract}

Stephen McLoughlin, Department of Palaeobiology, Swedish Museum of Natural History, P.O. Box 50007, S-104 05 Stockholm, Sweden. steve.mcloughlin@nrm.se

Benjamin Bomfleur, Department of Palaeobiology, Swedish Museum of Natural History, P.O. Box 50007, S10405 Stockholm, Sweden. Benjamin.Bomfleur@nrm.se

Thomas Mörs. Department of Palaeobiology, Swedish Museum of Natural History, P.O. Box 50007, S-104 05 Stockholm, Sweden. Thomas.Mors@nrm.se

Marcelo Reguero. División Paleontología de Vertebrados, Museo de La Plata, Paseo del Bosque s/n, B1900FWA La Plata, Argentina. mreguero@dna.gov.ar

Keywords: branchiobdellids, new genus, new species, spermatozoa, La Meseta Formation, Antarctic Peninsula

Submission: 23 October 2015 Acceptance: 11 March 2016

http://zoobank.org/42B578E7-5E4C-42FF-A24C-B5671CBD903E

McLoughlin, Stephen, Bomfleur, Benjamin, Mörs, Thomas, and Reguero, Marcelo. 2016. Fossil clitellate annelid cocoons and their microbiological inclusions from the Eocene of Seymour Island, Antarctica. Palaeontologia Electronica 19.1.11A: 1-27

palaeo-electronica.org/content/2016/1448-eocene-annelid-cocoons 


\section{INTRODUCTION}

Clitellata is a clade of annelids that includes earthworms, leeches, acanthobdellids (spiny leeches), and branchiobdellids (crayfish worms). Extant clitellate annelids live in soils, moist terrestrial habitats, and freshwaters on all continents with the exception of Antarctica, although they are sparse and of low diversity on some Antarctic islands (Erséus and Grimm, 2002; Rodriguez and Rico, 2008). Clitellatans are characterized most notably by the presence of a clitellum-a set of specialized body segments in the anterior half of the body that plays an important role during reproduction. Their anatomical simplicity and the plasticity of key morphological characters of the body hinder precise taxonomic resolution of groups within extant Clitellata (Novo et al., 2011). Greatest taxonomic resolution has been achieved using molecular data (Apakupakul et al., 1999; Martin, 2001; Siddall et al., 2001; Erséus and Källersjö, 2004; Rousset et al., 2007; Marotta et al., 2008; Struck et al., 2011; Weigert et al., 2014) and ultrastructural characters of spermatozoa (Jamieson and Rouse, 1989; Ferraguti and Erséus, 1999; Cardini and Ferraguti, 2004; Marotta and Ferraguti, 2009), although such data are not yet available for fossils, and the relationships inferred among some groups are still disputed.

\section{The Fossil Record of Clitellata}

Clitellate annelids have a poor and disputed body fossil record owing to their simple body form and lack of a robust exo- or endoskeleton (apart from rare setae and mouthparts in a few taxa; Wills, 1993). Although there are some marine clitellate annelids, the evolution of this group included one or more major shifts from marine to freshwater, mire, and soil environments that probably occurred alongside the colonization of the land by plants in the early to mid-Palaeozoic (Sawyer, 1986; Humphreys, 2003). Putative body-fossil impressions have been reported sporadically in fossil-Lagerstätten as old as the Ordovician (Kozur, 1970; Conway Morris et al., 1982; Mikulic et al., 1985; Wills, 1993). However, convincing body fossil evidence of modern clitellate groups has only been forthcoming from Cenozoic strata (Conway Morris et al., 1982). Edwards and Lofty (1977) suggested that clitellate annelids diversified in tandem with angiosperms and the development of closed forests as recently as the Cretaceous. By contrast, molecular dating has inferred differentiation of the clitellate crown group by the Permian, and with a stem group extending back to the late Cambrian (Parry et al.,
2014). Thus far, a body fossil record providing the means to test the inferred timing of cladogenesis within Clitellata is lacking.

Clitellate annelids have presumably left an extensive ichnofossil (burrow and trail) record, but these traces are difficult to ascribe to any particular group within the clade. Equivalent traces are produced by a wide range of other burrowing and crawling organisms, e.g., other annelids, nematodes, nemertean worms, hemichordates, molluscs, and some arthropods, amongst other invertebrates, especially in marine and coastal environments (Seilacher, 2007). In the absence of a rich macro- body fossil record, and owing to the difficulties in confident attribution of trace fossils to Clitellata, the distinctive and highly resilient reproductive cocoons probably hold the greatest potential for tracing the evolutionary history of major groups within this clade through geological time. To date, this potential has been hindered by a poor understanding of the diversity of both fossil and modern clitellate annelid cocoons.

\section{Clitellate Cocoon Formation and Preservation}

At the time of reproduction, clitellate annelids secrete cylindrical to ovoid cocoons around the clitellum (Sayers et al., 2009). A mucous secretion provides a scaffold onto which successive layers of proteinaceous material are deposited in characteristic arrangements (see figure 1 of Jansson et al., 2008; and figure 2 of Bomfleur et al., 2015). Generally, eggs and sperm are then released into the cocoon by the adult as the animal withdraws. The cocoon is finally sealed with an operculum and deposited on a stable substrate. It then cures over several hours to days to form a resistant case protecting the eggs and developing embryos. The operculum may be demarcated by a narrow band of attenuated wall material or it may have an ultrastructure or chemistry that differs slightly from the main cocoon (Coleman et al., 2008; Rossi et al., 2013), allowing it to detach or decompose to facilitate the emergence of the young. Consequently, fossil cocoons typically lack the operculum (Manum et al., 1991), although isolated opercula have been recovered in rare cases (Jansson et al., 2008).

Fossil clitellate annelid cocoons are common and widespread in post-Palaeozoic continental strata but there have been few detailed studies of these fossils (Manum et al., 1991 and references therein). In most cases, cocoons have simply been noted or illustrated in passing within palynological or palaeobotanical surveys (Harris, 1926; Michael, 
1936; Singh, 1964; Gunther and Hills, 1972; Douglas, 1973; Hueber, 1982; Baldoni and Taylor, 1985; LaPasha and Miller, 1985; Kovach and Dilcher, 1988). In many cases, these mesofossils have been misidentified. They have long been reported by palynologists and palaeobotanists in residues of sedimentary samples processed by acid bulk-maceration, and have been attributed to an array of plant, animal, fungal, and algal sources (Horst, 1954; Hughes, 1955; Krassilov, 1972; Melchior and Hall, 1983; Manum, 1996). Clitellate affinities for such fossils had been invoked over 150 years ago (Gergens, 1861), but this early identification was overlooked by later workers, probably owing to its publication as a short note in German. The majority of subsequent reports favoured affinities with plants (e.g., as sporangial linings or seed membranes), owing to their apparent compositional similarity to acid-resistant sporopollenin and cuticle, or invertebrate eggs, owing to their lack of regular surface ornamentation, sac-like structure and minute size. Manum et al. (1991) undertook the most recent detailed survey of such fossils and corroborated their identity as clitellate annelid cocoons. These structures are composed of one or more layers of a waxy secretion, which was originally named hirudoin by Zick (1933)—a term adopted by palaeontologists (Manum et al., 1991) but not employed widely by neontologists. The composition of hirudoin is poorly resolved, but biochemical studies of the walls of extant Clitellata cocoons have identified the dominant component to be a Cys-rich protein (Mason et al., 2004), which appears to contribute to the extraordinary resilience of these mesofossils to heat, pressure, and strong oxidizing agents (Sawyer, 1986; Manum et al., 1991). The physical and chemical resilience of cocoons has resulted in their extensive fossilization and regular recovery from bulk-macerated (i.e., hydrofluoric acid (HF) treated) palynological and plant mesofossil assemblages (Manum, 1996; Jansson et al., 2008).

\section{Classification of Clitellate Cocoons}

Only three genera have been established for fossil clitellate cocoons thus far: Dictyothylakos Horst 1954 emend. Manum et al., 1991, Burejospermum Krassilov 1972 emend. Manum et al., 1991 and Pilothylakos Manum et al., 1991. These genera are differentiated by characters of the wall architecture. All fossil cocoons described to date have two layers: an inner dense sheet-like layer termed alytine; and an outer loosely threaded or felt-like layer termed hapsine by Manum et al.
(1991). Burejospermum is characterized by a robust alytine layer with relatively weakly developed hapsine (Figure 1.1). Pilothylakos is similar to Burejospermum in having a solid alytine layer but has a much more extensively developed hapsine of fine felt-like threads (Figure 1.2). Dictyothylakos has a robust net-like hapsine but lacks or has only a poorly developed alytine that is commonly lost during diagenesis or laboratory processing (Figure 1.3). We describe a fourth genus, Pegmatothylakos, characterized by a distinctive robust reticulate layer exterior to the hapsine (Figure 1.4). The hapsine and alytine layers appear to possess essentially identical chemical constituents. Both layers consist of secreted thread-like structures. These threads differ in their arrangement, being loosely distributed in the hapsine, but densely packed or bound in laminae in the alytine. Some modern leeches differ in having two relatively homogenous wall layers covered by a loosely convoluted outer, ridged layer (Dimitriu et al., 2006).

There is some ambiguity over the categorization of clitellate cocoons as either body fossils or trace fossils. Because the cocoons represent saclike chambers secreted by the adult hermaphroditic clitellate annelid, and do not constitute a component of the normal body wall or exoskeleton, these structures might strictly be considered trace fossils and categorized as Calichnia (biogenic structures created for breeding purposes; Genise and Bown, 1994). However, Bertling et al. (2006, p. 266) made a distinction between the remains of "secretions without subsequent manipulation by the producer", such as eggs, pearls, larval puparia of flies and the cocoons of clitellate annelids (which they classified as body fossils), and secretions that undergo a subsequent step of manipulation by the producer to form recurrent structures, such as silk nets, webs, or woven cocoons (which they considered to be trace fossils). This distinction is probably not unambiguous in all cases, because at least some clitellate cocoons show potential manipulation of the secreted threads to form recurrent architectural components (see descriptions below). However, to avoid segregation of some clitellate annelid cocoons as body fossils and others as trace fossils, we follow Genise (2004) and Bertling et al. (2006) in treating all clitellate cocoons, secreted for the protection of the eggs, as body(-part) fossils. An alternative nomenclatural approach was proposed by Manum et al. (1991, p. 349) who coined the term "hapsidarch" as an informal group name for acid-resistant secreted cocoons by analogy with the term "acritarch" (Evitt, 1963)—an informal 


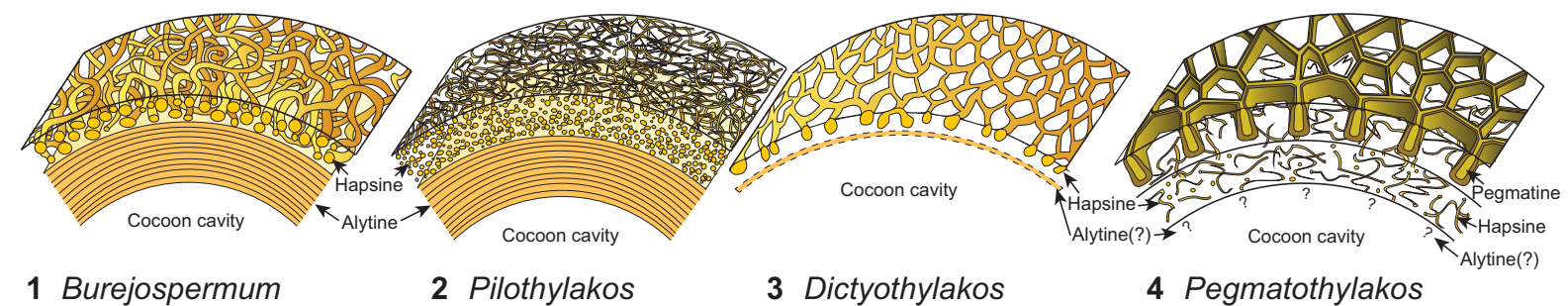

FIGURE 1. Diagrammatic sections through the walls of fossil clitellate annelid cocoons showing the general structure and representation of layers. 1, Burejospermum. 2, Pilothylakos. 3, Dictyothylakos. 4, Pegmatothylakos.

group name used in palynology for organic-walled microfossils of apparently unicellular algal origin, but lacking characters enabling definitive assignment to taxa. However, the term hapsidarch has not gained usage in subsequent studies.

\section{Palaeobiological Significance of Clitellate Cocoons}

Interest in clitellate fossils has increased recently owing to the remarkable discovery of softbodied micro-organisms and the world's oldest known animal spermatozoa entombed within the alytine layer of fossil cocoons (Manum et al., 1994; Bomfleur et al., 2012, 2015). This style of preservation is similar to entombment in amber, although the size of the entombed remains is obviously limited by the small size of the cocoons (normally $<10$ $\mathrm{mm}$ in diameter). Such discoveries provide a new window on the overall sparse fossil record of softbodied micro-organisms and yield insights into additional microenvironments and trophic levels within ancient ecosystems. Moreover, the presence of abundant spermatozoa entrapped within the cocoon's inner wall can provide insights into the evolutionary history of reproductive strategies within the group (e.g., hypodermal injection versus free release of spermatozoa).

Here we describe three new species of clitellate cocoons, one in a new genus, from lower Eocene nearshore marine to estuarine strata of Seymour Island, Antarctica. We evaluate the architecture of the cocoons and illustrate the range of biological inclusions entrapped within the secreted cocoon walls. Further, we assess the affinities, environmental significance, and stratigraphic implications of these acid-resistant mesofossils.

\section{GEOLOGICAL SETTING}

\section{Stratigraphy and Depositional Environment}

Seymour Island is situated at $64^{\circ} 17^{\prime} \mathrm{S}$ in the Weddell Sea, near the northern tip of the Antarctic
Peninsula (Figure 2). It is the only place in Antarctica with a Paleogene terrestrial animal fossil record, although the poorly consolidated sediments of the middle Paleocene to upper Eocene/?lowermost Oligocene Seymour Island Group, which yielded these fossils, were deposited in proximal submarine fans, shelf settings and deltaic environments (Elliot, 1988). These strata are part of the James Ross Basin, a back-arc basin developed on the eastern flank of the Antarctic Peninsula (Elliot, 1988; Del Valle et al., 1992; Hathway, 2000). Most of the terrestrial fossils are found in the Eocene La Meseta Formation (Elliot and Trautman, 1982), which represents the 720-m-thick poorly consolidated sandstone, mudstone, and shell-rich conglomerate fill (Figure 3.1-3) of a 7-km-wide incisedvalley system (Marenssi et al., 1998, 2002; Marenssi, 2006). Fossil material sampled for this study derives from the estuarine, unconformitybounded Cucullaea I Allomember of Marenssi et al. $(1998,2002)$ and Marenssi (2006) (i.e., level 35 of Montes et al., 2013), belonging to the informal biozone 'Telm 5' of Sadler (1988). Cucullaea I Allomember deposits are characterized by parallel lamination, climbing ripples, flaser- and wavy bedding, small-scale channels, invertebrate burrows, and shell lenses (Elliot and Trautman, 1982; Sadler, 1988; Stilwell and Zinsmeister, 1992). Most of these shell lenses are dominated by the thickshelled bivalve Cucullaea, but one layer is dominated by the naticid gastropod Polynices, many of them predated by their kin. This 'Natica horizon' constitutes lenses up to $1 \mathrm{~m}$ thick that pinch out laterally over a few metres (Figure 3.4 ), but can be traced at several sites along the western flanks of the northern Seymour Island plateau. Besides marine mollusks (see Stilwell and Zinsmeister, 1992), marine vertebrates are also abundant in the 'Natica horizon', including teeth and placoid scales of sharks, skates, rays, and chimaerans, together with teeth and bones of teleosts, basilosaurid whales, and penguins (Reguero et al., 2013; 


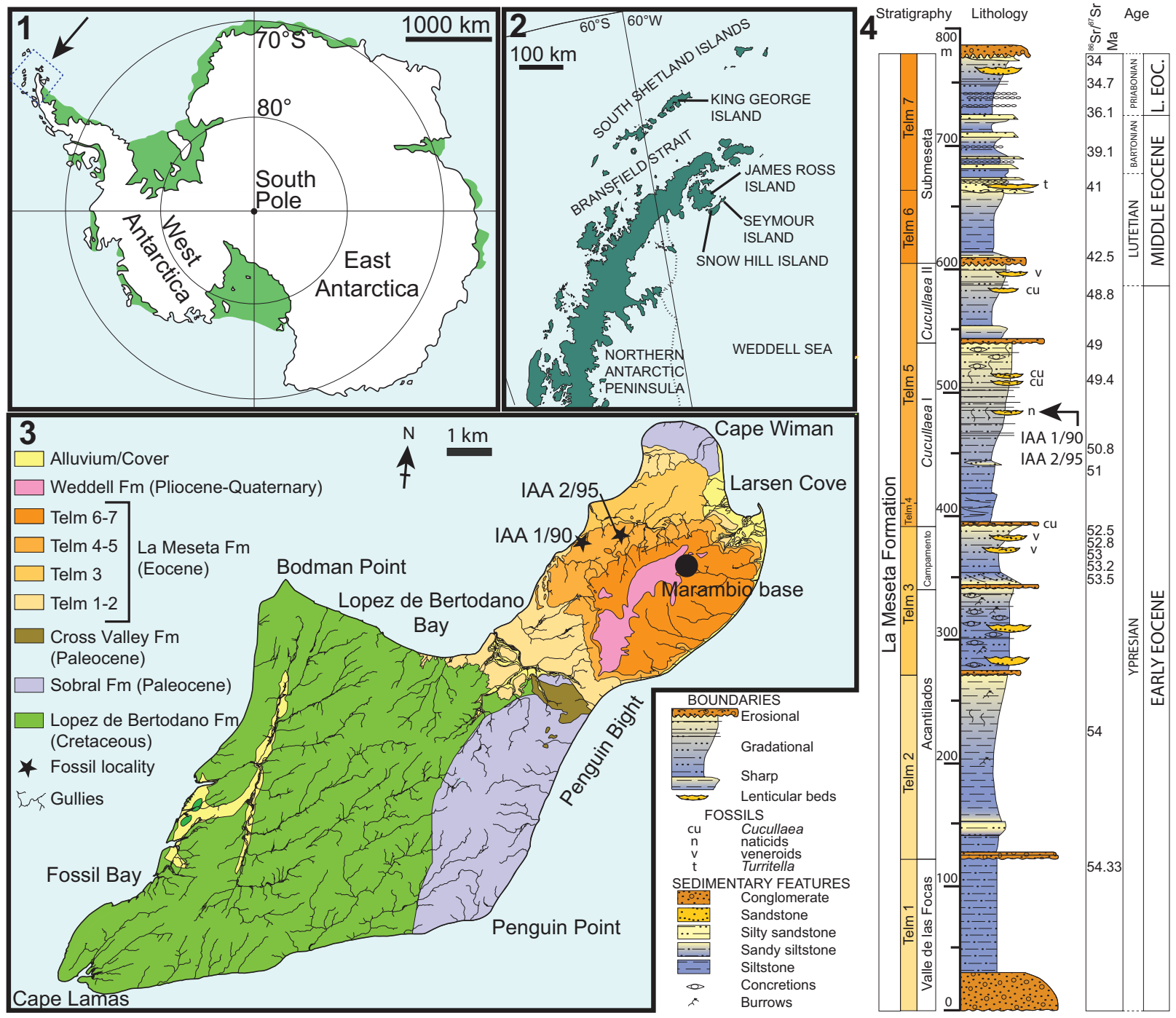

FIGURE 2. Locality maps and stratigraphic column of the studied succession. 1, Map of Antarctica showing the location of the study area. 2, Map of the northern Antarctic Peninsula showing the location of Seymour Island. 3, Geological sketch map of Seymour Island, Antarctic Peninsula, showing the positions of fossil localities IAA 1/90 and IAA 2/ 95. 4, Stratigraphic column of the La Meseta Formation on Seymour Island (from Reguero et al., 2013). Strontium date values from Dingle and Lavelle (1998), Dutton et al. (2002), Reguero et al. (2002), and Ivany et al. (2008).

Schwarzhans et al., in press). In addition, these shell lenses have yielded the remains of a broad range of terrestrial organisms, including mammal teeth and bones (e.g., gondwanatheres, marsupials, and ungulates; see Woodburne and Zinsmeister, 1984; Goin and Carlini, 1995; Bargo and Reguero, 1998; Goin et al., 2006; Gelfo et al., 2009, 2015; Bond et al., 2011; Reguero et al., 2013), dispersed seeds, and fossil wood that is usually heavily bored by teredinid bivalves denoting extended immersion in normal marine waters (Savrda, 1991; McLoughlin et al., 1995).

\section{Age of the La Meseta Formation}

There is broad consensus that the age of the Cucullaea I Allomember of the La Meseta Formation is Eocene, but over the past two decades researchers have debated as to whether this unit's age is early, middle, or even late Eocene. Stilwell and Zinsmeister (1992) suggested a late Eocene age based on a biostratigraphic assessment of struthiolariid gastropods. Strontium isotope ratios $\left({ }^{87} \mathrm{Sr} /{ }^{86} \mathrm{Sr}\right.$ ) from bivalve shells were used by Dutton et al. (2002) to argue for a middle Eocene age (44.5 or $47.4 \mathrm{Ma}$ ). However, more resolved strontium data of Ivany et al. (2008) provided a late early 


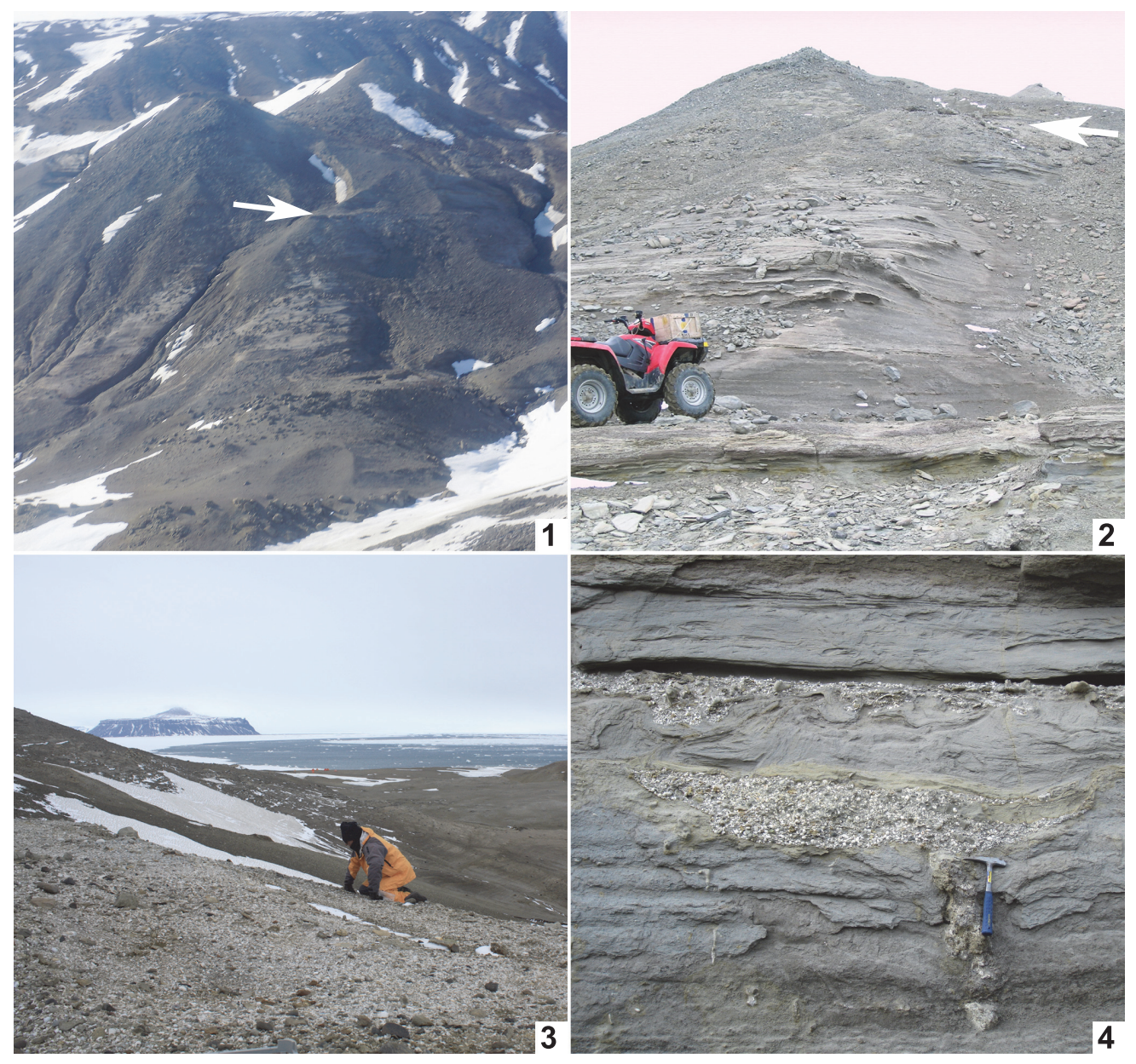

FIGURE 3. Photographs of sampling localities. 1, Aerial view of 'Ungulate site' (IAA 1/90, 64'14'04.67"S, $56^{\circ} 39^{\prime} 56.38 \mathrm{WW}$ ) with 'Natica horizon' marked by arrow. 2, Detail of section between Cucullaea 1 bed (below quad bike) and 'Natica horizon' at IAA 1/90 (arrowed) showing dominance of poorly consolidated sandstones, mudstones and shell-rich conglomerates. 3, Panoramic view of 'Marsupial site' (IAA 2/95: 64 ${ }^{\circ} 13^{\prime} 58^{\prime \prime} \mathrm{S}, 56^{\circ} 39^{\prime} 06^{\prime \prime} \mathrm{W}$ ) with 'Natica horizon' exposed along foreground ridge, and Cockburn Island in background. 4, 'Natica horizon' near site IAA 2/95 showing incised base and lenticular character of the bed. Photographs by T. Mörs (1, 2), F. Degrange (3), and J. Hagström (4).

Eocene age (49-51 Ma; see Figure 1.4). This greater age $(\sim 49.5 \mathrm{Ma})$ was confirmed by Gelfo et al. (2009) and Tejedor et al. (2009) who correlated the mammal assemblage from the Cucullaea I Allomember with that of the Patagonian Paso del Sapo assemblage, whose age is well constrained by radiometric dates. In contrast, Douglas et al. (2014) proposed an age younger than late middle Eocene $(\sim 41 \mathrm{Ma})$ for Telm 5 on the basis of its dinoflagellate cyst assemblage-an age inconsistent with other recent data. Montes et al. (2013) reevaluated all previous temporal constraints on the La Meseta Formation in their stratigraphic synthesis of the Seymour Island succession and resolved that the Cucullaea I Allomember is Ypresian (early Eocene) in age, ranging from 52.8 Ma at the base to $49.0 \mathrm{Ma}$ at the top. We employ their age determinations for the Seymour Island stratigraphic succession herein.

\section{MATERIALS AND METHODS}

\section{Material}

The studied material consists of several complete and fragmentary cocoons, most of which derive from locality IAA $1 / 90$ (GPS data: $64^{\circ} 14^{\prime} 04.67^{\prime \prime S}$; 56³9'56.38"W, Figures 2.3; 3.1-3), informally known as the 'ungulate site' (Marenssi et al., 1998) owing to the discovery of the first Antarctic ungulates (Bond et al., 1990). IAA 1/90 is the richest Antarctic mammal-bearing locality known to date (Chornogubsky et al., 2009). It exposes a con- 
glomeratic lens that is almost $1 \mathrm{~m}$ thick and that extends laterally for several metres before thinning. The lens consists of fine- to coarse-grained sand with abundant bioclasts (mainly naticids) and pebbles up to $20 \mathrm{~cm}$ in diameter. The lens at IAA 1/90 is situated within the Struthiolarella steinmanni Zone of Stilwell and Zinsmeister (1992). The second locality yielding clitellate annelid cocoons is IAA 2/95 (GPS data: 64¹3'58"S; 56³9'06"W, Figures 2.3 ; 3.4 ), also known as the 'marsupial site' owing to the discovery of marsupial remains at this location. The host deposit at this site is also a conglomeratic lens with a lithology similar to that at IAA $1 / 90$.

All material, prefixed NRM, is held in the collections of the Swedish Museum of Natural History (Naturhistoriska Riksmuseet). The letter ' $S$ ' in specimen numbers denotes registration within the fossil plant and mesofossil collections of this institution.

\section{Methods}

The cocoon fossils were obtained from sediment samples that were dry-sieved in the field using $20 \mathrm{~mm}$ mesh screens in order to obtain a residue cleared of larger stones and mollusc fragments. The residue was further dry-sieved in the laboratory and separated into finer fractions $(>4.0$, $>2.0,>0.5 \mathrm{~mm}$ ) in order to search for microvertebrate remains. The cocoons were hand-picked from the $>2 \mathrm{~mm}$ fraction using a stereomicroscope during this screening process.

Once separated from the remaining fossil residues, individual cocoons were immersed in $38 \%$ HF for 30 minutes to remove adhering silicate particles and then rinsed with water. Light micrography of specimens was undertaken using a Nikon Digital Sight DS-2Mv camera fitted to a Zeiss Stemi SV11 stereo-microscope. Selected specimens were mounted on aluminium stubs, coated with gold, and imaged using a Hitachi S-4300 field emission scanning-electron microscope at the Swedish Museum of Natural History. The ultrastructure of a portion of the cocoon wall from one specimen was studied via synchrotron-radiation-based X-ray tomographic microscopy (SRXTM) at the TOMCAT beamline of the Swiss Light Source at the Paul Scherrer Institute, Switzerland. This specimen was mounted on a 3-mm-diameter brass stub and examined using the technique outlined by Donoghue et al. (2006) with a beam energy of $10 \mathrm{kV}$ and a $20 \times$ objective. Slice data were obtained over $180^{\circ}$ rotation and in 1501 stepwise increments, and were subsequently analyzed, reconstructed, and manipulated using Avizo software.

\section{Terminology}

We follow the terminology established by Manum et al. (1991) and Manum (1996) for characters of fossil cocoon walls. We introduce the new term pegmatine (from the Greek pegma = a framework or scaffold) for a rigid, dark, single-layered reticulate framework external to the felt-like hapsine layer in some cocoons. The term 'girders' is used to describe the individual, robust, laminated, interconnected struts that comprise the reticulate pegmatine layer.

\section{SYSTEMATIC PALAEONTOLOGY}

Phyllum ANNELIDA Lamarck, 1809

Class CLITELLATA Michaelsen, 1919

Order and Family uncertain

Genus BUREJOSPERMUM Krassilov, 1972

emend. Manum, Bose and Sawyer, 1991

Type Species. Burejospermum crassitestum Krassilov, 1972, by original designation.

Burejospermum seymourense sp. nov.

Figures 4.1-3; 5; 6

zoobank.org/9745DE12-F572-4117-9300-56E7EC77A240

Holotype. NRMS089727 (Figures 4.1-3).

Type Locality, Stratum, and Age. Locality IAA 2/

95; 'Natica horizon' within the Cucullaea I Allomember (Telm 5) of the La Meseta Formation; early Eocene.

Additional Material. NRMS089730NRMS089732 (from the type locality).

Etymology. After Seymour Island.

Diagnosis. Reddish-brown barrel-shaped cocoons $<4 \mathrm{~mm}$ long. Hapsine over most of the cocoon wall comprising disorganized threads more densely amalgamated in gently sunken equatorial girdle. Plate-like secretions locally developed on the outer surface of hapsine. Alytine dense, consisting of tightly amalgamated threads, and locally containing blind tubular cavities parallel to cocoon surface. Description. Cocoon reddish-brown in reflected and transmitted light (Figure 4.1), ellipsoidal, 2.4 $\mathrm{mm}$ long from the anterior terminus to the level of the operculum detachment (estimated total length $3 \mathrm{~mm}$ ); diameter $2 \mathrm{~mm}$; essentially circular in cross-section except where crushed by burial compaction. Anterior end broadly rounded. Posterior operculum absent from studied specimens (Figure 4.2). Hapsine 5-75 $\mu \mathrm{m}$ thick (Figures 5.5, 6.10) consisting of moderately dense threads interconnected and interwoven to form a thin, brownish, 

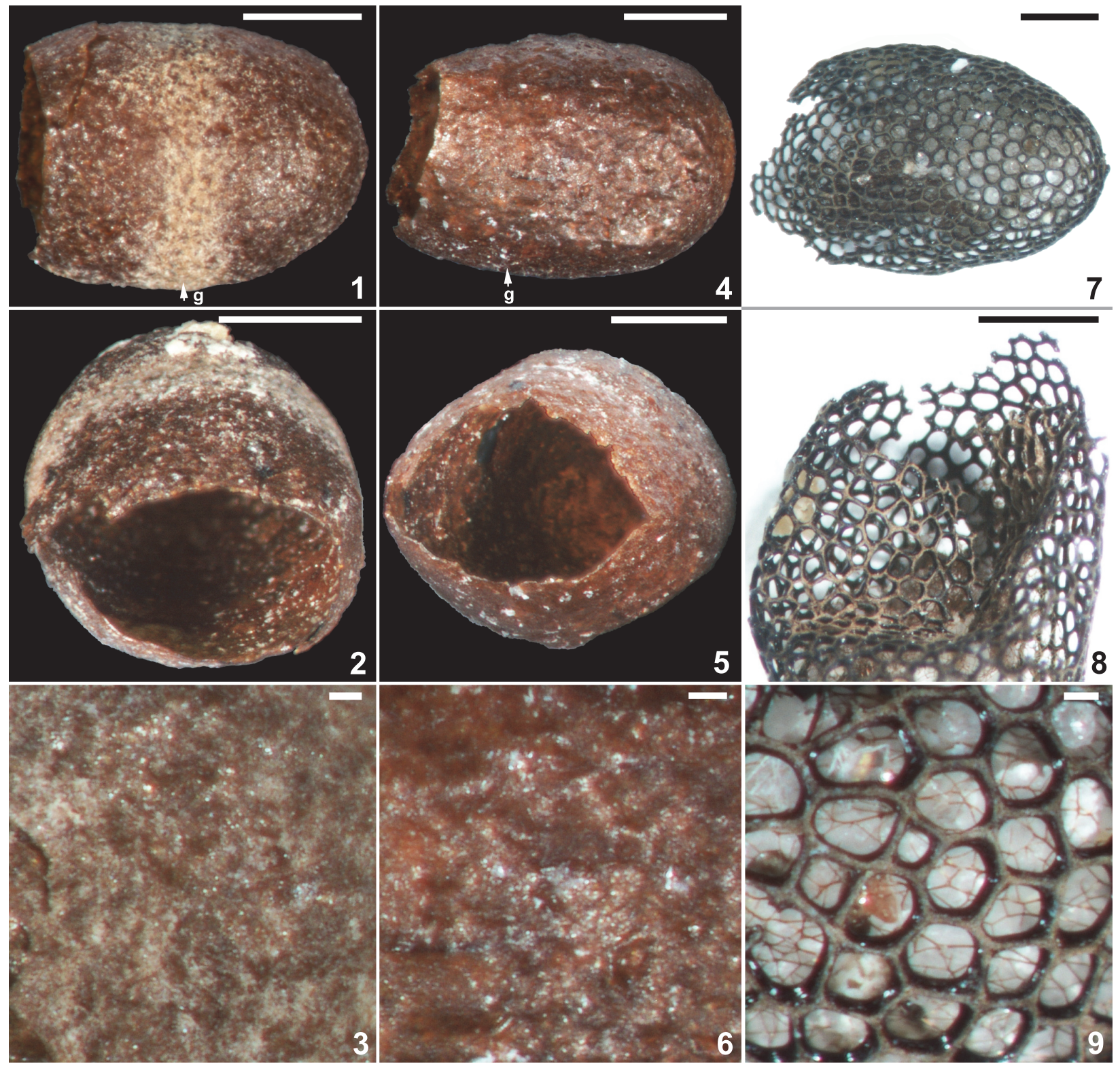

FIGURE 4. Light micrographs of early Eocene clitellate annelid cocoons from Seymour Island. 1-3, Burejospermum seymourense sp. nov. (NRMS089727). 4-6, Burejospermum punctatum sp. nov. (NRMS089728). 7-9, Pegmatothylakos manumii sp. nov. (NRMS089730). 1, 4, 7, Lateral views of cocoons (posterior to left); $g$ = equatorial girdle. 2, 5, 8 , Views of posterior end of cocoons showing opening left by detachment of operculum. 3, 6, 9, Enlargements of cocoon wall exterior showing pale felt-like hapsine covering in $B$. seymourense (3), relatively smooth surface in $B$. punctatum (6) and reticulate pegmatine of $P$. manumii (9). Scale bars represent $1 \mathrm{~mm}$ in 1, 2, 4, 5, 7, 8; $100 \mu \mathrm{m}$ in 3, 6, 9.

felt-like covering on the cocoon (Figures 4.3, 5.2, 6.1, 6.9; Supplementary Animation 1). Threads typically $\sim 3 \mu \mathrm{m}$ thick, locally reaching $10 \mu \mathrm{m}$ thick. Hapsine of consistent density throughout except for a 350- $\mu \mathrm{m}$-wide, slightly depressed, pale (whitish to yellowish in reflected light) girdle (Figures $4.1,5.1$ ) bearing more densely spaced and amalgamated threads (Figure 5.3). Isolated, flat, elliptical patches or plates of secreted material, 40-60 $\mu \mathrm{m}$ long, 32-45 $\mu \mathrm{m}$ wide and $<3 \mu \mathrm{m}$ thick distributed sparsely on outer hapsine surface (Figure 5.4, 5.6).

Alytine composed of secreted threads amalgamated into numerous thin sheets to form a continuous densely laminated layer $\sim 22 \mu \mathrm{m}$ thick (Figures 5.5, 6.10). Inner surface of alytine is smooth or undulated (Figure 6.2). Alytine incorporating sparse tubular cavities $>400 \mu \mathrm{m}$ long and 
$25 \mu \mathrm{m}$ wide, parallel to cocoon surface, mostly in equatorial regions. Tubes lined by threads deflected towards one end of the cavity forming a pseudo-braided or chevron pattern (Figure 6.3-8; Supplementary Animations 2-4).

Remarks. Burejospermum seymourense differs from the two other taxa in the Seymour Island assemblage by its combination of a dense alytine layer and a robust hapsine that stands proud of the alytine surface. It differs from previously described Burejospermum species by its small dimensions, the distinct pale equatorial girdle of dense hapsine threads and the presence of sparse elliptical platelike secretions on the outer surface of the hapsine. Burejospermum seymourense is the most common cocoon form in the Seymour Island assemblage. All specimens represent hatched cocoons (lacking an operculum).

The tubular cavities oriented parallel to the surface within the alytine layer (Figure 6.2-8; Supplementary Animations 2-4) are of uncertain origin. Manum et al. (1991) devoted considerable attention to equivalent structures in other examples of Burejospermum and, although they did not identify any analogue among modern clitellate annelid cocoons, they hypothesized that such structures may have been produced by individual setae on a clitellar segment that became embedded in the alytine during the process of hirudoin secretion. They proposed that the setae were subsequently extracted from the tubes as the animal's clitellar region contracted before egg-laying. The chevronshaped threads lining the tubes in the Seymour Island specimens, and the flaring of the tube at one end (Supplementary Animation 4), are consistent with the hypothesis of distortion caused by extraction of setae before the cocoon wall had hardened. However, we note that this hypothesis is tempered by the observation that modern true leeches and branchiobdellids (the two groups most commonly invoked as the producers of hapsinerich fossil clitellate cocoons: Manum et al., 1991; Bomfleur et al., 2015) lack setae (Smith, 2001).

\section{Burejospermum punctatum sp. nov.} Figures 4.4-6; 7

zoobank.org/D51D3E3F-C6F1-498C-BBDA-960761C7E2D6

Holotype. NRMS089728 (Figures 4.4-6; 7). Type Locality, Stratum, and Age. Locality IAA 2/ 95; 'Natica horizon' within the Cucullaea I Allomember (Telm 5) of the La Meseta Formation; early Eocene.

Additional Material. NRMS089733 (from the type locality).
Etymology. After the locally punctate nature of the outer surface of the alytine.

Diagnosis. Reddish-brown cocoons $<4 \mathrm{~mm}$ long. Hapsine very weakly developed, consisting of irregularly interconnected slender threads that may be depressed locally into the outer layer of the alytine. Alytine composed of numerous densely amalgamated laminae forming a solid wall with irregularly spaced circular pits on its outer surface. Weakly developed, densely granulate girdle positioned slightly to the posterior of cocoon equator.

Description. Cocoon deep reddish-brown in reflected (Figure 4.4) and transmitted light; ellipsoidal (Figure 7.1) with broadly rounded anterior end. Posterior end lacking operculum in all cases (Figure 4.5). Cocoon $3 \mathrm{~mm}$ long between anterior terminus and the line of operculum detachment (estimated length $\sim 3.5 \mathrm{~mm}$ including operculum); diameter $2.4 \mathrm{~mm}$; essentially circular in cross-section except where crushed. Hapsine weakly developed (Figure 4.6) or locally absent (Figure 7.3); where present it is composed of slender threads interconnected to form an irregular reticulum that is commonly depressed into the outer layer of the alytine (Figure 7.2). Hapsine threads $<4 \mu \mathrm{m}$ (typically $\sim 2 \mu \mathrm{m}$ ) thick.

Alytine composed of numerous $(>25)$ thin (0.5-1 $\mu \mathrm{m}$ thick) laminae densely amalgamated to form a solid layer $\sim 24 \mu \mathrm{m}$ thick (Figure 7.6). Outer surface of alytine commonly bearing irregularly spaced, circular pits up to $10 \mu \mathrm{m}$ in diameter and $<10 \mu \mathrm{m}$ deep (Figure 7.3); surface otherwise relatively smooth except where it is densely granulate in a weakly developed $400-\mu \mathrm{m}$-wide girdle (Figure 7.4) positioned sightly to the posterior of the equator. Outer alytine surface with minute, short $(80 \mu \mathrm{m}$ long, $\sim 20 \mu \mathrm{m}$ wide), parallel cleft-and-fold structures (Figure 7.5); inner alytine surface smooth.

Remarks. Burejospermum punctatum differs from all other species in the genus by its relatively smooth outer surface, i.e., by having a very weakly developed hapsine that, to varying degrees, is depressed into the outer surface of the alytine. Cocoons of this type are similar in size, shape and colour to $B$. seymourense, so it is conceivable that they represent variability of cocoon development by a single cocoon maker. However, we did not observe any intermediate forms between these two cocoon types, so we propose that they were produced by different species of clitellate annelids. Only sparse examples of spermatozoa entrapment were identified between the alytine laminae of this species (described below). 

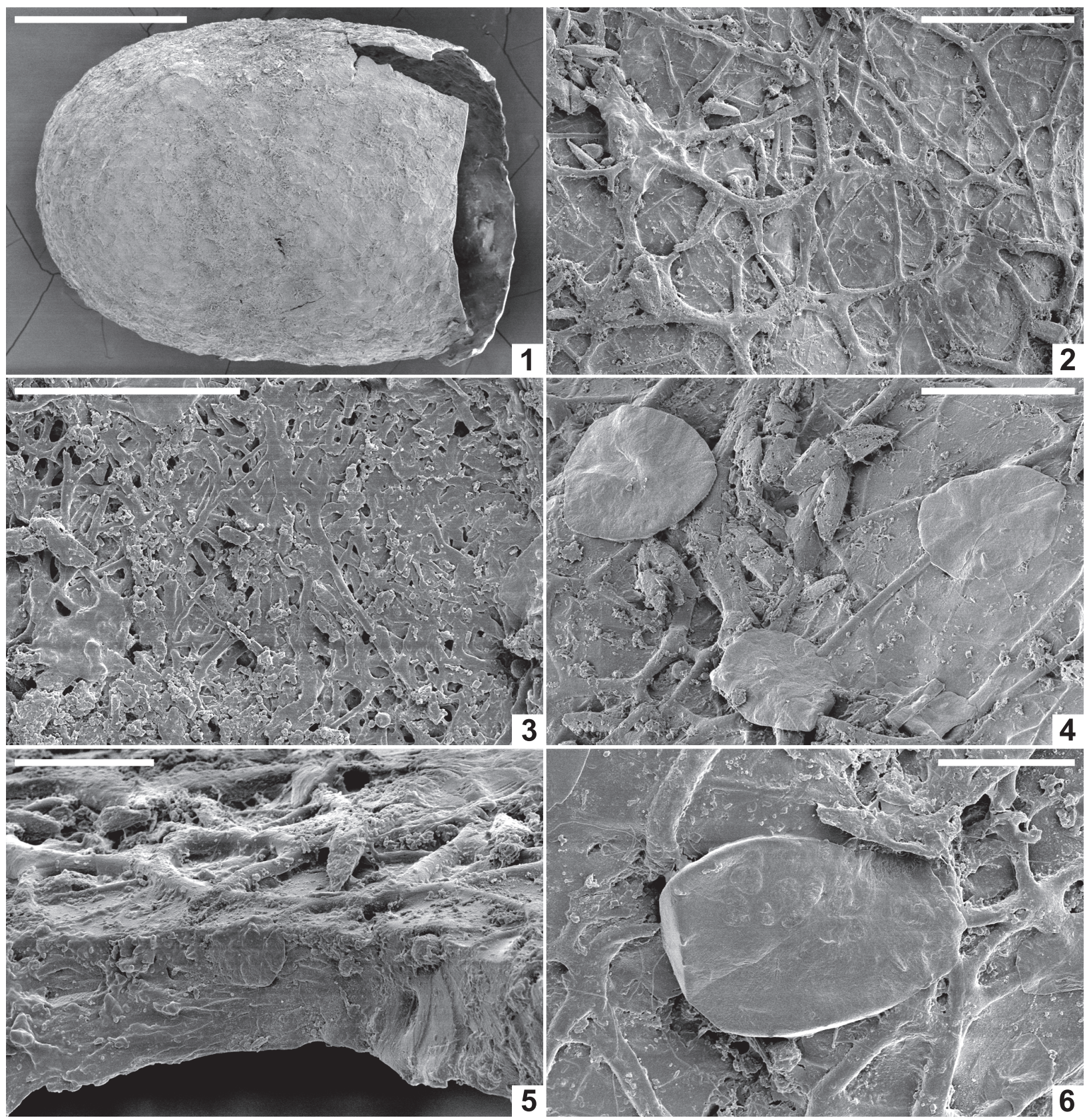

FIGURE 5. Scanning electron micrographs of Burejospermum seymourense sp. nov. (NRMS089727). 1, Cocoon in lateral view. 2, Details of typical hapsine threads. 3, Detail of dense hapsine threads over girdle region. 4, Elliptical secreted plate-like structures on exterior of hapsine. 5, Broken cocoon wall in cross-section showing solid alytine (lower) and thread-like hapsine (upper). 6, Detail of plate-like secretion on exterior of hapsine. Scale bars represent 1 $\mathrm{mm}$ in 1; $100 \mu \mathrm{m}$ in 2; $50 \mu \mathrm{m}$ in 3, 4; $25 \mu \mathrm{m}$ in 5, 6 .

Genus PEGMATOTHYLAKOS gen. nov. zoobank.org/339BAEBC-42C6-46E3-B480-61B6E3E8CA4D Type Species. Pegmatothylakos manumii sp. nov., by monotypy.

Etymology. Greek: pegma - a scaffold or framework; thylakos - sac. Gender: neuter.
Diagnosis. Fossil cocoons lacking an obvious sheet-like alytine. Inner layer of cocoon consisting of irregular slender-threaded, mesh-like hapsine. Outer layer of cocoon (= pegmatine) representing a shell of rigid girders interconnected to form a semi- 


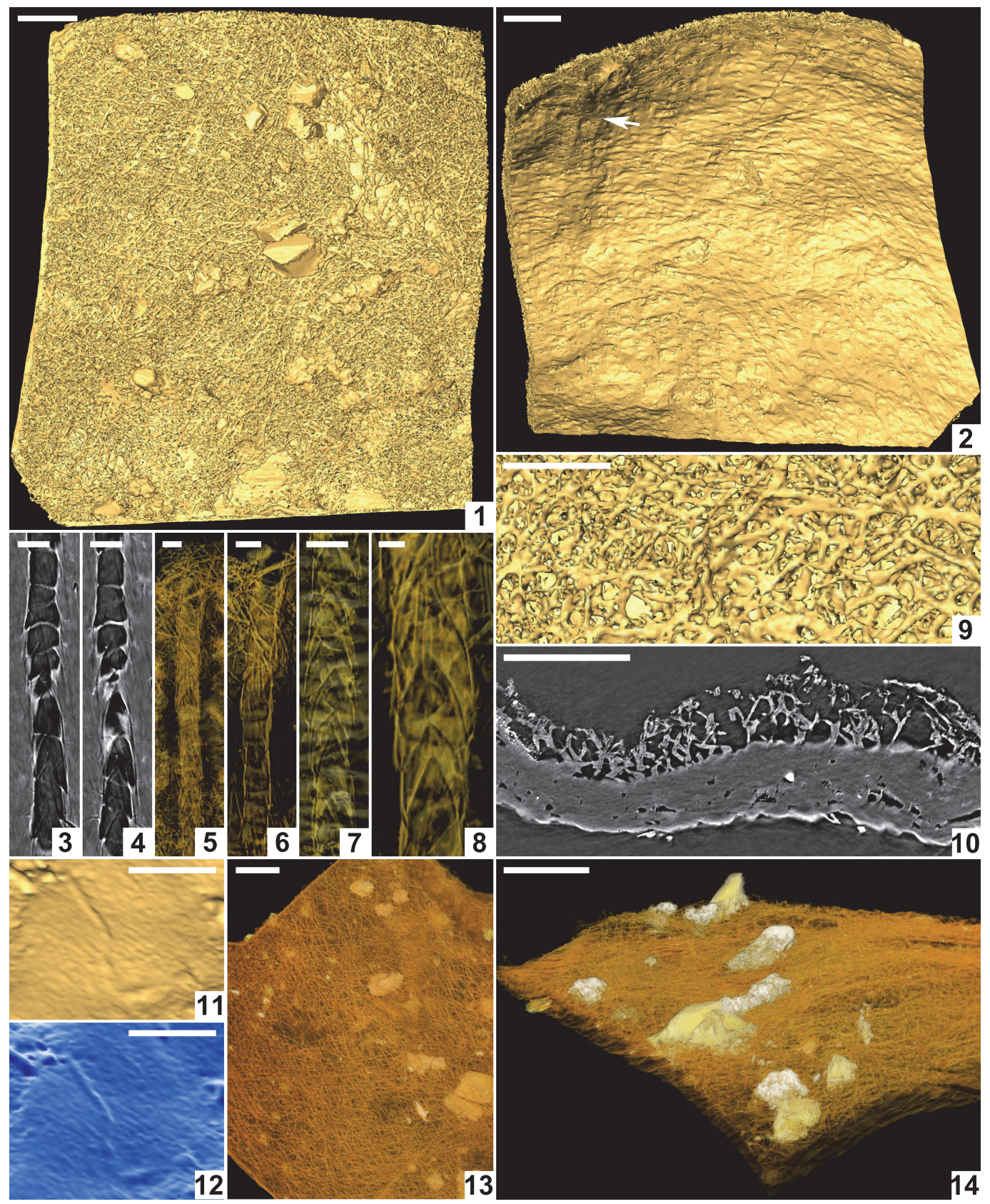

FIGURE 6. Computed tomographic images of a Burejospermum seymourense cocoon wall (NRMS089729) generated from Synchrotron-radiation-based X-Ray tomographic microscopy (SRXTM) at the TOMCAT beamline of the Swiss Light Source at the Paul Scherrer Institute, Switzerland. 1, Isosurface rendering of cocoon's external surface showing mineral grains embedded in hapsine. 2, Isosurface rendering of cocoon's internal surface showing creasing caused by alytine threads. Arrow indicates the position of a hollow tube within the alytine. 3, 4, Longitudinal orthoslice sections, at different focal planes, of a tube within the alytine showing pseudosegmentation. 5-8, Translucent volume rendering of a tube within the alytine imaged at different focal planes and magnifications to highlight the transverse to chevron-shaped thread arrangement lining the tube wall. 9, Isosurface rendering of hapsine outer surface showing details of the complex arrangement of hirudoin threads. 10, Transverse orthoslice section of the cocoon wall showing the near-solid alytine layer (bottom) and mesh-like hapsine layer (top). 11, Isosurface rendering of interior alytine wall showing an embedded spermatozoal nuclear region. 12, Colour-inverted rendering of Figure 6.11. 13, Volume rendering of the cocoon wall showing numerous mineral (white-yellow) inclusions. 14, Oblique translucent volume rendering of the cocoon wall showing the distribution of mineral grains mainly in the outer hapsine layer. Scale bars represent $100 \mu \mathrm{m}$ in $1,2,10,13,14 ; 50 \mu \mathrm{m}$ in $\mathbf{9} ; 25 \mu \mathrm{m}$ in $3-7 ; 10 \mu \mathrm{m}$ in $8 ; 5 \mu \mathrm{m}$ in 11, 12. 

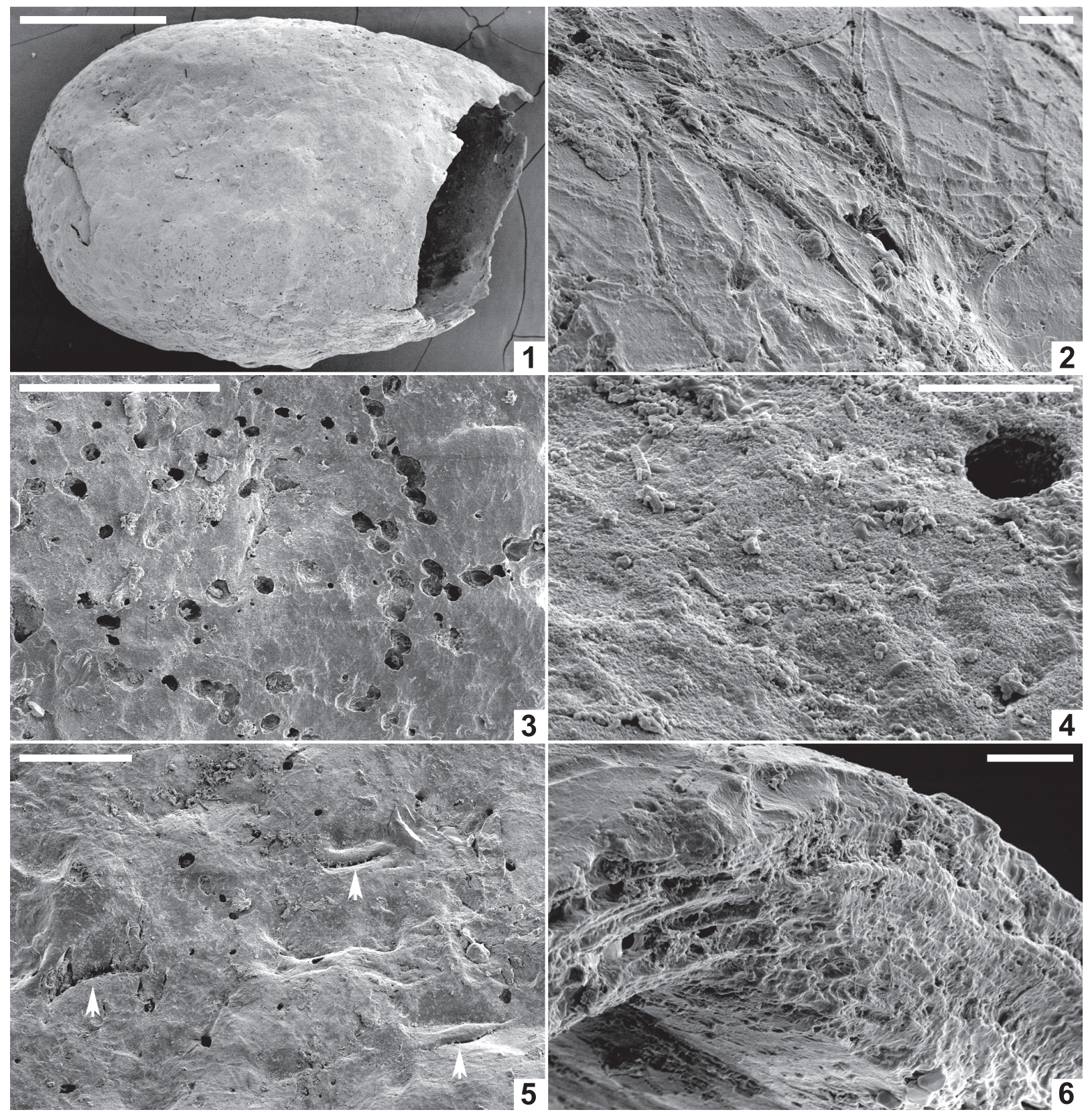

FIGURE 7. Scanning electron micrographs of Burejospermum punctatum sp. nov. (NRMS089728). 1, Cocoon in lateral view. 2, Details of sparse hapsine threads embedded in alytine surface. 3, Detail of typical cocoon surface showing pitting. 4, Detail of girdle region showing granular microtexture and a single surface pit. 5, Detail of outer alytine surface showing cleft and fold structures (arrowed). 6, Cross-section of cocoon wall showing laminated architecture. Scale bars represent $1 \mathrm{~mm}$ in 1; $100 \mu \mathrm{m}$ in 3, 5; $10 \mu \mathrm{m}$ in 2, 4, 6 .

regular reticulate framework enclosing roundedpolygonal lumina.

Remarks. This is the fourth genus established for fossil clitellate annelid cocoons. The genus is unique in lacking any obvious sheet-like alytine layer and in possessing a robust, rigid, reticulate framework layer (pegmatine) external to the felt- like hapsine (Figure 1.4). The pegmatine also differs from the outermost (hapsine) layer of other fossil clitellate cocoons in being dark brown to black rather than yellow to red in reflected light, thus suggesting some difference in its chemistry. The hapsine of Pegmatothylakos is otherwise similar to the equivalent layer in Burejospermum and 
Dictyothylakos species, but less dense than that in Pilothylakos.

Pegmatothylakos manumii sp. nov. Figures 4.7-9; 8

zoobank.org/21970058-1A59-424A-855E-CE1BAEE14E9A

Holotype. NRMS089730 (Figures 4.7-9; 8).

Type Locality, Stratum, and Age. Locality: IAA 1/ 90; 'Natica horizon' within the Cucullaea I Allomember (Telm 5) of the La Meseta Formation; early Eocene.

Additional Material. NRMS089734, locality: IAA 2/95; 'Natica horizon' within the Cucullaea I Allomember (Telm 5) of the La Meseta Formation; early Eocene.

Etymology. After Professor Svein Bendik Manum (1926-2015), Norwegian palaeobotanist, who carried out the first major survey of fossil clitellate annelid cocoons.

Diagnosis. Cocoon ellipsoidal, $<6 \mathrm{~mm}$ long. Pegmatine dark brown to black in reflected light, consisting of a semi-regular reticulum of girders enclosing circular, elliptical, or rounded-polygonal lumina mostly $\sim 75-200 \mu \mathrm{m}$ in diameter. Girders consisting of a core of fibrous or hackly material coated on the lateral and interior surfaces by multiple flattened strips of smooth, tightly overlapping threads. Hapsine amber-coloured, consisting of loosely interwoven slender threads.

Description. Cocoon ellipsoidal (Figure 4.7, 8.1); $4.6 \mathrm{~mm}$ in preserved length (estimated complete length $\sim 5 \mathrm{~mm}$ ), $\sim 3 \mathrm{~mm}$ in equatorial diameter, circular in cross-section except where crushed; anterior end broadly rounded; posterior end damaged in all examples but potentially operculate (Figure 4.8). Outer shell (pegmatine) consisting of a semiregular reticulate network of girders enclosing roughly equidimensional (rounded-polygonal, broadly elliptical, or circular) lumina with maximum dimensions of 50-220 $\mu \mathrm{m}$ (Figures 4.9, 8.2). Girders consisting of two components-a core of brown fibrous or hackly material 20-35 $\mu \mathrm{m}$ thick (Figure 8.6), and a lateral- and interior-surface coating of multiple flattened strips of subsequently secreted dark brown to black glossy dense threads that tightly overlap (Figure 8.3-5) and locally bifurcate in complex arrangements (Figure 8.7). Girders are $\sim 50 \mu \mathrm{m}$ thick and $50-80 \mu \mathrm{m}$ wide. Rare spermatozoal fragments and other inclusions are entrapped between the laminar threads coating the inner surface of the pegmatine girders (described below).

Hapsine positioned to the interior side of the pegmatine but not obviously attached. Hapsine weakly developed, consisting of slender $(2-8 \mu \mathrm{m}$ diameter), amber-coloured, cylindrical, sparsely branched threads arranged in a loose, complex interwoven felt-like meshwork (Figure 8.8).

Remarks. Only two specimens are available of this newly described taxon, but its unique architecture incorporating a robust pegmatine reticulum enables the species to be readily differentiated from all other fossil clitellate annelid cocoons. Attribution to Clitellata is based on the presence of a hapsine layer, apparently operculate character, and the sporadic occurrence of diagnostic spermatozoa inclusions embedded between the pegmatine filaments.

The pupal sacs of some Diptera, Coleoptera, Lepidoptera, and Neuroptera are enveloped by an external meshwork that is somewhat reminiscent of the pegmatine layer of Pegmatothylakos. However, such pupal casings are constructed in an essentially woven manner, i.e., having a succession of continuous threads that are superimposed in moreor-less opposite directions and subsequently connected. By contrast, the pegmatine in Pegmatothylakos has multiple layers of threads delineating individual rounded-polygonal lumina without any apparent hierarchical relationship in girder structure. We hypothesize that the formation of the pegmatine may-unlike that of a woven or otherwise coordinated construction-result, at least in part, from the self-organization of the girders on some ephemeral scaffold, possibly a mucous foam- or bubble-layer, at the time of cocoon secretion. Additional differences are the more variable and greater size of the lumina in the reticulum of insect pupal casings, and the much greater separation of the reticulum from the inner pupal sac (see, e.g., Eiseman and Charney, 2010; Holland, 2010).

Some insect eggs (especially those of lepidopterans) also have morphologies superficially similar to the reticulate structure of Pegmatothylakos (Sourakov and Emmel, 1995; Dunn, 2010), and several examples of ornate Mesozoic insect eggs have recently been described in detail (e.g., Pott et al., 2008; Heřmanová and Kvaček, 2010; Heřmanová et al., 2013; Fisher and Watson, 2015). However, both modern and fossil insect eggs have complex wall anatomies and surface morphologies with reiterating patterns (Hinton, 1970, 1981; Ren, 1992; Wolf and Reid, 2001; Fisher and Watson, 2015) that allow their differentiation from annelid cocoons.

\section{INCLUSIONS WITHIN THE COCOON WALLS}

Micro-biological structures (Figures 6.11-12, 9) and sparse mineral particles (Figure 6.13-14) are entombed within both the alytine and hapsine 


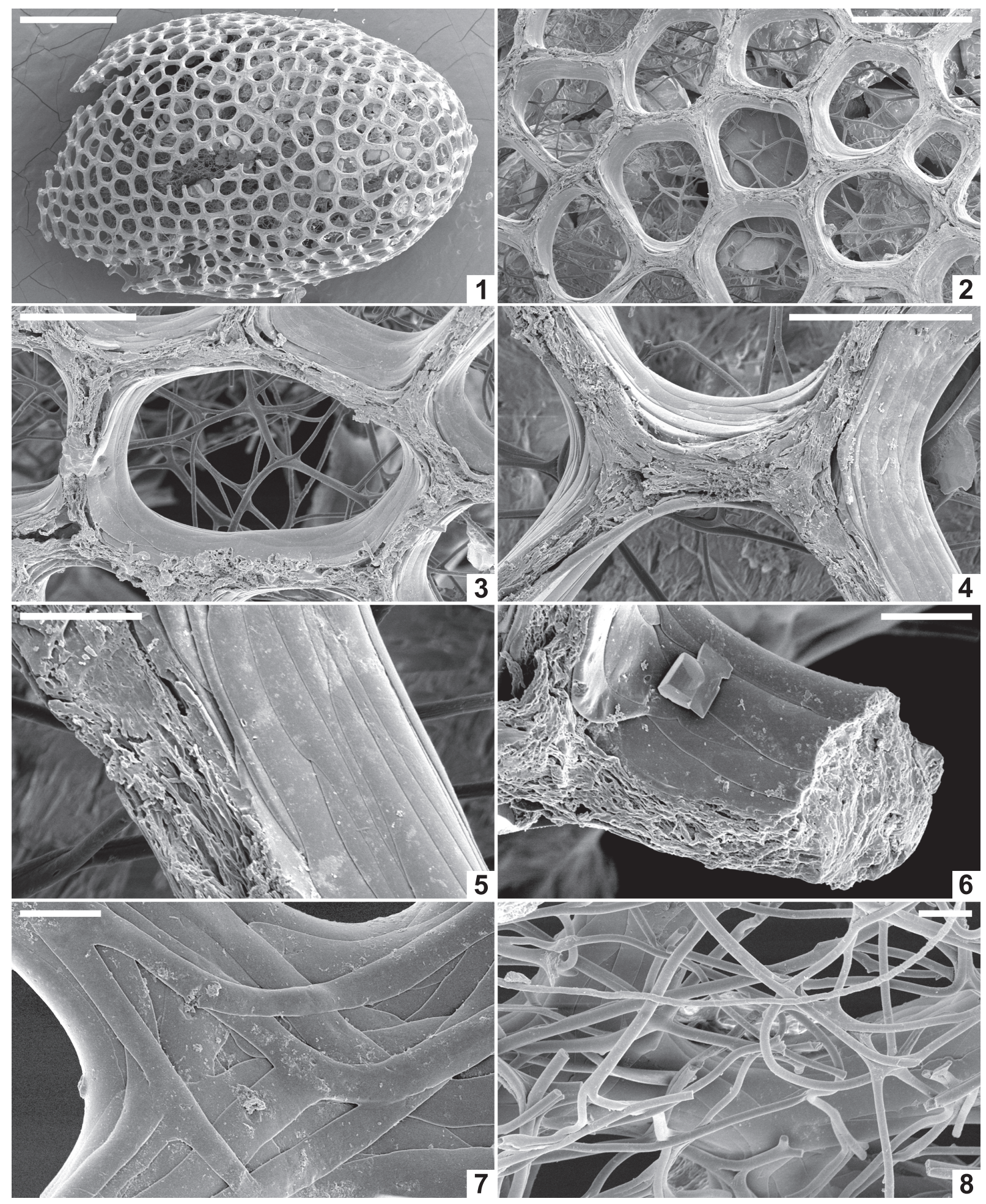

FIGURE 8. Scanning electron micrographs of Pegmatothylakos manumii sp. nov. (NRMS089730). 1, Cocoon in lateral view. 2, Enlargement of robust reticulate pegmatine covering thread-like hapsine. 3, Enlargement of areole in pegmatine reticulum showing underlying mesh-like hapsine. 4, Enlargement of girders forming pegmatine showing hackly inner zone and smoothly welded threads lining girder margins. 5, Detail of hackly and smooth threads in pegmatine girders. 6, Broken pegmatine girder showing irregular internal structure. 7, Enlargement of interior surface of pegmatine girder showing smooth threads with irregular branching and orientation. 8, Enlargement of hapsine threads. Scale bars represent $1 \mathrm{~mm}$ in 1; $250 \mu \mathrm{m}$ in 2; $100 \mu \mathrm{m}$ in 3, 4; $25 \mu \mathrm{m}$ in 5-8. 
layers of each cocoon taxon. The organic inclusions appear to be preserved as moulds (cavities from which all original organic matter has been lost) encased by very thin (nanometre-scale) coatings of hirudoin. Synchrotron x-ray tomographic microscopy could only detect the microbiological inclusions at the limit of applied beam resolution, and could not identify any internal structural features (Figures 6.11-12). Thus, we used primarily SEM for analysis of these wall inclusions. The minute size ( $<500 \mathrm{~nm}$ in diameter) of most inclusions inhibits acquisition of crisp high-resolution SEM images of unequivocal spermatozoan moulds in cross-section. Therefore, we illustrate all examples in surface view, which provides diagnostic details of the microfossils' external morphologies (Figures 9.1-14).

Bomfleur et al. (2015) identified the oldest fossilized animalian spermatozoa entombed within the alytine of one specimen of Burejospermum seymourense (NRMS089729) from the Seymour Island assemblage, pre-dating by over 10 million years previous examples of fossil sperm cells reported from collembollans in late Eocene amber (Poinar, 2000), and from ostracods in early Miocene phosphorite (Matzke-Karasz et al., 2014). Here we describe and illustrate an additional array of entombed structures to those outlined by Bomfleur et al. (2015) in order to document the full diversity of micro- and nanofossils preserved in the clitellate cocoon walls.

\section{Spermatozoa}

Fossil spermatozoa are most readily observable and abundant within the innermost alytine laminae of Burejospermum seymourense (Figure 9.1-3, 9.5-12). However, sparse spermatozoal fragments were also identified within the alytine of $B$. punctatum (Figure 9.13) and in the innermost pegmatine of Pegmatothylakos manumii (Figure 9.14). The spermatozoa of $B$. seymourense are typically incomplete-in most cases the anterior acrosome or 'drill bit' structure having detached. We interpret the complete spermatozoon of this species to consist of (from anterior to posterior): 1, an apical button ( $300 \mathrm{~nm}$ long and wide; Figure 9.2); 2, a tightly coiled acrosome (8-18 $\mu \mathrm{m}$ long, $\sim 500 \mathrm{~nm}$ wide) with a swollen tip that probably contains the acrosome vesicle $(1.2 \mu \mathrm{m}$ long, $800 \mathrm{~nm}$ wide; Figure 9.2-3); 3, a granular-ornamented nuclear region that tapers distally $(2.75-4 \mu \mathrm{m}$ long, 500$650 \mathrm{~nm}$ in maximum width; Figure 9.5, 9.7, 9.9, 9.11-12); 4, a granular to weakly striate mitochondrial region (1-1.2 $\mu \mathrm{m}$ long; Figure 9.11) that also tapers distally; and 5, a whip-like flagellum (18 $\mu \mathrm{m}$ to at least $25 \mu \mathrm{m}$ long, $\sim 160 \mathrm{~nm}$ wide; Figure 9.5) that, in some cases, possesses anterior swellings (Figure 9.7) and commonly a beaded morphology (Figure 9.6, 9.8, 9.10) that may reflect the presence of a helical marginal fibre. The spermatozoa preserved within B. punctatum cocoons appear to be of essentially the same dimensions and architecture as those preserved within $B$. seymourense but have slightly tighter and narrower coils on the acrosome (Figure 9.13). Only ill-preserved spermatozoal fragments were observed in the cocoons of $P$. manumii (Figure 9.14), and these do not show morphological features that enabled differentiation from those of $B$. seymourense.

As noted by Bomfleur et al. (2015), the spermatozoa of $B$. seymourense have characters that suggest affiliation with branchiobdellids, especially the very long acrosome, granular nuclear region, and beaded structure of the flagellum that possibly reflects the presence of a helical marginal fibre-a feature unique to branchiobdellid spermatozoa. Given that the spermatozoa entrapped within the cocoons of $B$. punctatum and P. manumii are structurally similar to those of $B$. seymourense, they too probably have branchiobdellid affinities. These interpretations must be tempered by the observation that the full range of cocoon and spermatozoal morphologies of extant clitellate annelid groups has not yet been documented.

\section{Bacteria}

Numerous ellipsoidal, oblong, reinform, or spherical laevigate bodies are embedded in the alytine of $B$. seymourense cocoons (Figure 9.2, $9.4,9.5,9.7,9.12)$. The ellipsoidal, reinform, and oblong forms are 1.4-2 $\mu \mathrm{m}$ long and $500-900 \mathrm{~nm}$ in diameter. Spherical forms are typically smaller (500-750 nm in diameter) and commonly occur in chains or clusters (Figures 9.4-5; 10). Many of these structures have a characteristic circular to oblong dimple in their surface.

The lack of distinctive morphological features on these bodies prohibits definitive assignment to a particular biological group. However, based on their minute size, rounded termini, and occurrence in clusters or chains, we interpret these bodies to be probable bacterial bacilli and cocci. Extant bacteria are typically $500 \mathrm{~nm}$ to $5 \mu \mathrm{m}$ in maximum dimensions but they may range from $300 \mathrm{~nm}$ to $500 \mu \mathrm{m}$ (Robertson et al., 1975; Schulz and Jorgensen, 2001). The dimple-like structure on many specimens may be taphonomic (i.e., caused by desiccation or compression of the hirudoin coating 


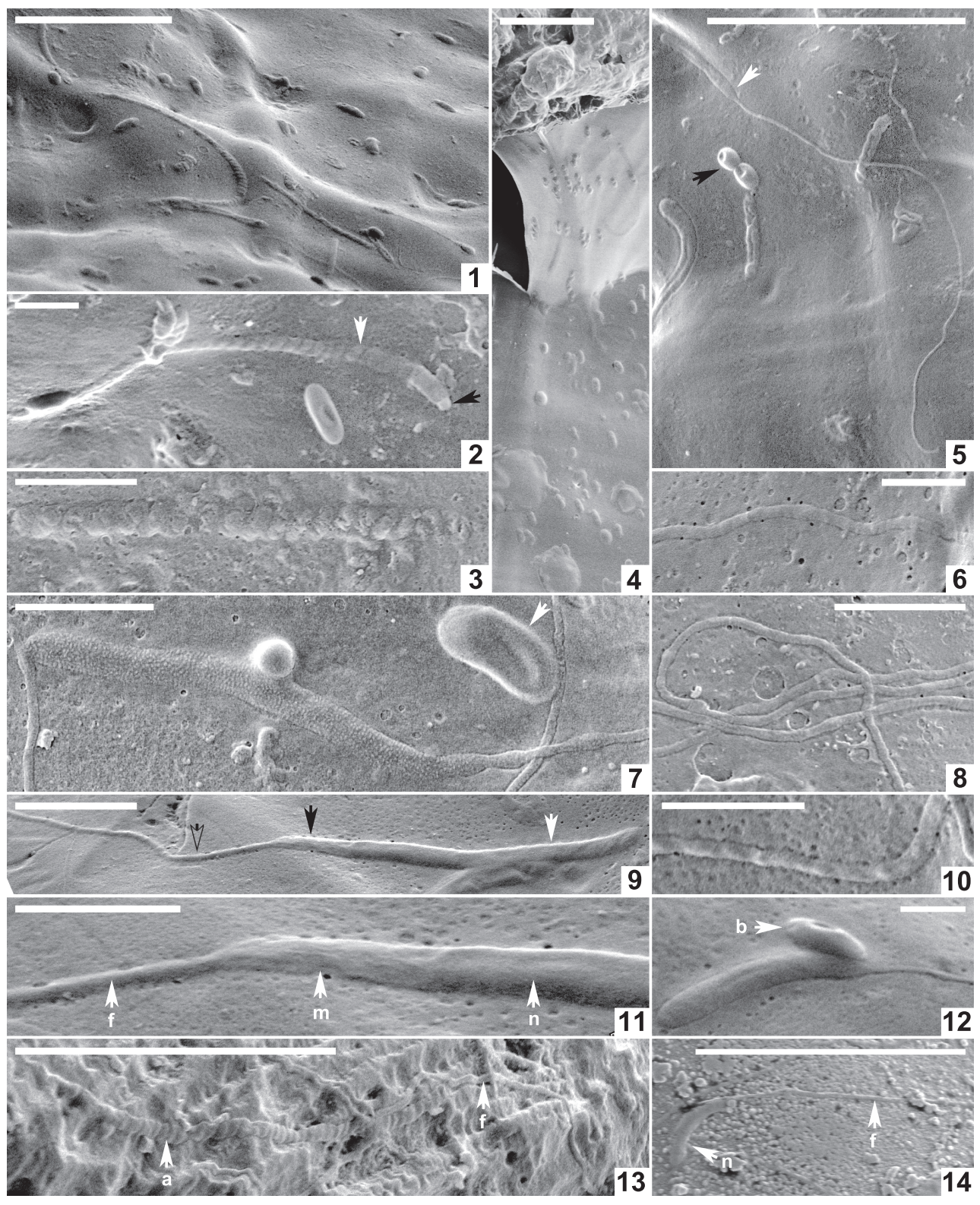

FIGURE 9. Spermatozoa and bacteria preserved embedded in the innermost layer of the alytine wall of Burejospermum seymourense sp. nov., NRMS089729 (1-12); Burejospermum punctatum sp. nov., NRMS089728 (13); and Pegmatothylakos manumii sp. nov., NRMS089730 (14). 1, Overview of cocoon inner surface showing a range of elongate spermatozoa and elliptical-reniform bacteria. 2, Spermatozoon acrosome (white arrow) with swollen tip (probably containing the acrosome vesicle) and apical button (black arrow). 3, Enlargement of a spirally organized detached acrosome. 4, Thin sheet-like innermost layer of alytine draped over mineral inclusion (top) and entombing numerous elliptical bacteria. 5, Several spermatozoal nuclear regions, one with an attached whip-like flagellum (white arrow). A pair of dimpled elliptical bacteria are also present in the upper left (black arrow). 6, Enlargement of a portion of a spermatozoon flagellum showing slightly beaded structure. 7, Enlargement of the nuclear and mitochondrial region of a spermatozoon showing granular ornamentation and swellings in the anterior portion of the attached flagellum. Reniform bacterium also present in upper right (white arrow). 8, Several spermatozoal flagella showing indistinct spiral architecture. 9, Nuclear (white arrow), mitochondrial (black arrow) and anterior flagellar (hollow arrow) regions of a spermatozoon. 10, Enlargement of a flagellum showing beaded structure that probably reflects helical architecture. 11, Enlargement of Figure 9.9 showing details of nuclear $(n)$, mitochondrial $(m)$ and anterior flagellar $(f)$ regions. 12, Overlapping elliptical bacterium (b) and flagellate spermatozoon. 13, Elongate coiled acrosome (a) and slender flagellum (f) of separate spermatozoa. 14, Nuclear $(n)$ and flagellar (f) regions of a spermatozoon. Scale bars represent 10 $\mu \mathrm{m}$ in $1,4,5,13,14 ; 2 \mu \mathrm{m}$ in $2,3,7-9 ; 1 \mu \mathrm{m}$ in $6,10-12$. 


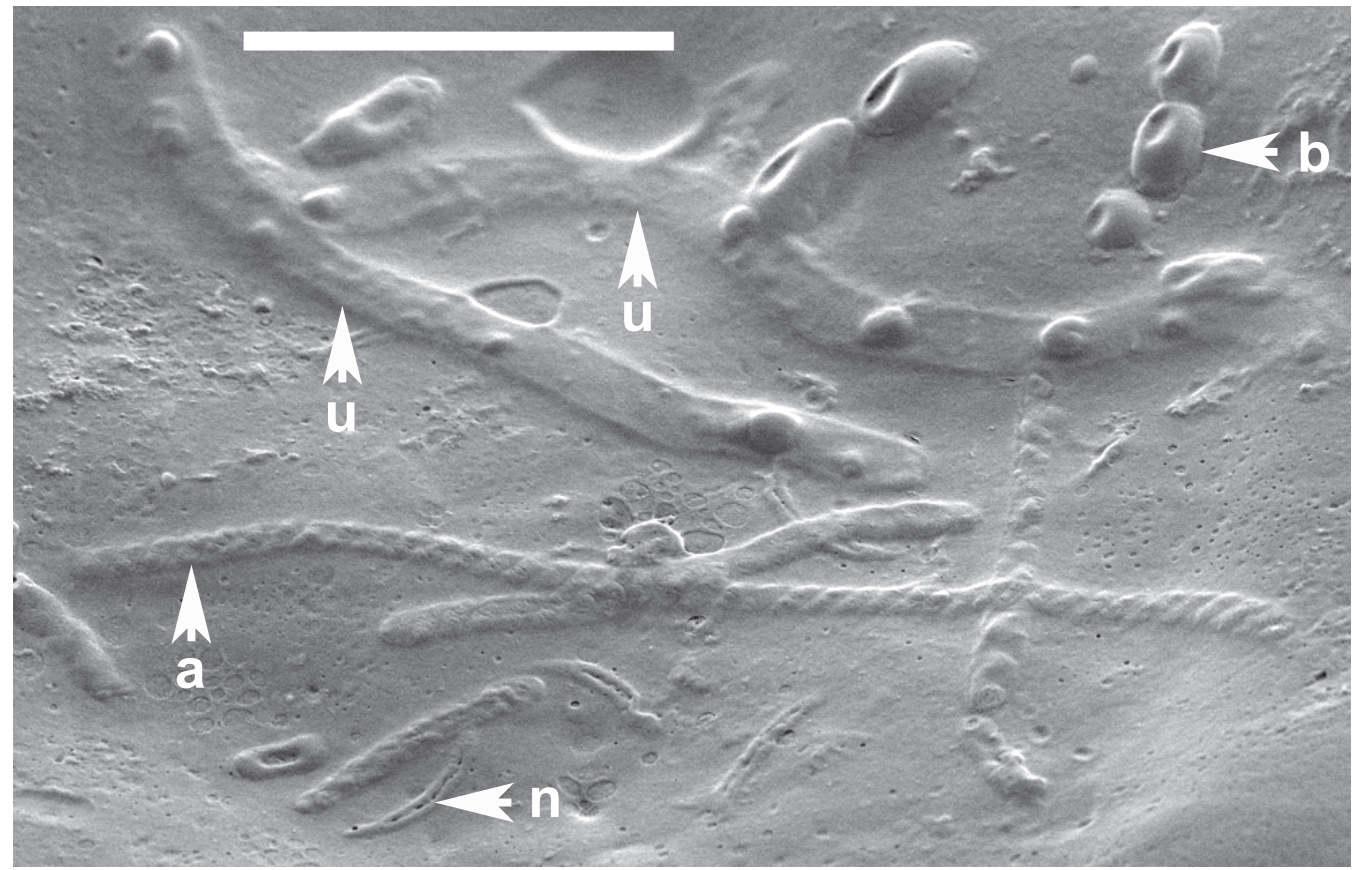

FIGURE 10. Organic inclusions embedded in the innermost layer of the alytine wall of Burejospermum seymourense sp. nov. (NRMS089729) $b=$ bacteria in a chain, $n=$ detached spermatozoal nuclear regions, $a=$ detached spermatozoal coiled acrosome regions, $u=$ unidentified vermiform bodies. Scale bar represents $5 \mu \mathrm{m}$.

into the hollow fossil mould) as several spermatozoal nuclear regions also bear a longitudinal crease (Figures $9.5 ; 10$ ).

\section{Vermiform Bodies}

Two vermiform bodies, $750-840 \mathrm{~nm}$ wide and 11.3-12 $\mu \mathrm{m}$ long are co-preserved with a range of spermatozoal fragments and bacteria in the wall of one specimen of Burejospermum seymourense (NRMS089729) (Figure 10). They are embedded deeply in the cocoon wall, have rounded termini, but are otherwise relatively featureless.

These structures are notably broader than copreserved spermatozoal acrosomes and lack the characteristic helical architecture of the latter. Manum et al. (1994) reported a nematode, Captivonema cretacea, preserved in an Early Cretaceous clitellate annelid cocoon from Spitsbergen. However, nematodes, including the Spitsbergen example, are typically an order of magnitude larger $(\sim 5-100 \mu \mathrm{m}$ in diameter, and at least $100 \mu \mathrm{m}$ long; Brady and Weil, 2009) than the Seymour Island vermiform structures. A metazoan origin can probably be excluded for these structures based on their diminutive size. Instead, the Seymour Island examples may represent elongate protists, such as microsporidia (typically 1-40 $\mu \mathrm{m}$ long and rod-like; Vávra and Larsson, 2014), or euglenoids (typically
10-500 $\mu \mathrm{m}$ long and elliptical, spindle-shaped or vermiform; Raven et al., 1986).

\section{DISCUSSION}

\section{Cocoon Affinities}

Egg/larva-bearing cocoons are secreted by most clitellate annelids, although asexual reproduction by paritomy (division at budding zones) or architomy (fragmentation) is common in some genera (Martin et al., 2008). Earthworm (= traditional 'oligochaete') cocoons are distinguished by the presence of prominent polar extensions on the cocoon and by lacking, or having only a very weakly developed, outer filamentous (hapsine) layer (Manum et al., 1991; Bhattacharjee and Chaudhuri, 2002) (Figure 11.1). Few acanthobdellid cocoons have been studied, but they appear to be ovoid with at least one polar extension (Kutschera and Epshtein, 2006). Modern hirudineans (leeches) have variable development of the mesh-like hapsine over the alytine layer (Dimitriu et al., 2006; Coleman et al., 2008) (Figure 11.2). Few branchiobdellid (crayfish worm) cocoons have been illustrated or described in previous studies. However, at least some cocoons attributed to this group are elliptical, with a smooth to weakly filamentous or scabrate outer layer, and at least one 

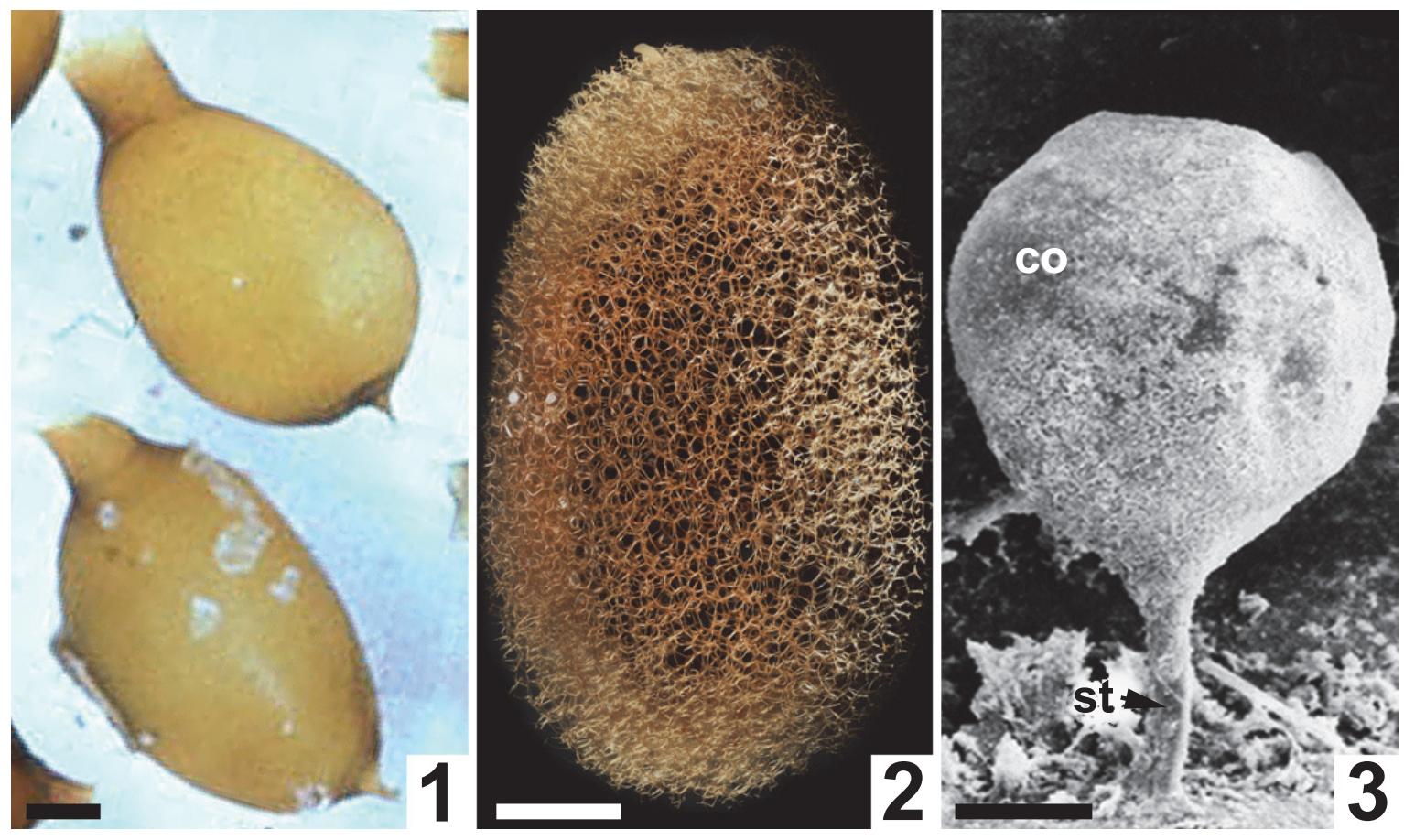

FIGURE 11. Comparative morphologies of extant clitellate annelid cocoons. 1, Light micrograph of two earthworm (Oligochaeta: Lumbricus terrestris) cocoons with prominent polar extensions and walls constructed almost entirely of the solid alytine layer (from Clive A. Edwards, The Ohio State University, Columbus, USA, Public domain via Wikimedia Commons). 2, Light micrograph of a true leech (Hirudinea: ?Macrobdella decora) cocoon with a wall dominated by a Dictyothylakos-like meshed hapsine layer (courtesy of Macroscopic Solutions, LLC. www.macroscopicsolutions.com). 3, Scanning electron micrograph of a crayfish worm (Branchiobdellida: Cambarincola macrocephelus or C. fallax) cocoon with a thin scabrate hapsine layer overlying solid alytine (courtesy of Dr Naglaa M SH Geasa, Tanta University, Egypt; after Geasa, 2014, figure 6G); co = cocoon body lacking an operculum; st = attachment stalk. Scale bars represent $1 \mathrm{~mm}$ in 1, 2; $50 \mu \mathrm{m}$ in 3.

prominent polar extension forming an attachment to the commensal crayfish host (Quaglio et al., 2006; Geasa, 2014) (Figure 11.3).

Whereas the development of a distinctive twolayered architecture has provided support for Burejospermum, Dictyothylakos and Pilothylakos having affinities to hirudineans in past studies (Manum et al., 1991; Manum, 1996), a potential affinity with branchiobdellids has been largely overlooked. Based on the distinctive spermatozoa associated with all three cocoon types described in this study and by Bomfleur et al. (2015), the producers may have been branchiobdellids, and if so, then these remains would represent the first fossil evidence of this clade. Moreover, modern branchiobdellids are restricted to the Northern Hemisphere so the Antarctic fossils would indicate a greater biogeographic range for this group in the Paleogene and imply extinction of that group in the Southern Hemisphere subsequent to the early Eocene. Alternatively, the cocoons may belong to an extinct lineage of Clitellata that shared some characters with branchiobdellids.

The architecture of Pegmatothylakos does not correspond precisely to that of any known modern clitellate group. It is atypical in having a rigid framework layer (pegmatine) exterior to the felt-like hapsine. It is possible that Pegmatothylakos possessed a very thin and delicate, sheet-like, alytine layer that was destroyed during transport, diagenesis or sieving. This layer is commonly degraded or very weakly developed in Dictyothylakos (Manum et al., 1991) (Figure 1.3), so its absence in Pegmatothylakos may be a taphonomic artefact. In some respects, the pegmatine (outermost layer) of Pegmatothylakos resembles the alytine (innermost layer) of Burejospermum and Pilothylakos in being composed of tightly bound laminae or threads, but its semi-regular reticulate architecture, contrasting colour, and the two-component architecture of the pegmatine girders is quite different to the paler and relatively simple sheet-like structure of Burejospermum alytine. For these reasons we 
consider that these layers are not strictly homologous. Nevertheless, the broad similarities (in shape, size, and secreted-thread construction) between Pegmatothylakos and other clitellate cocoons favours attribution to Clitellata, and the former may represent the cocoons of an unrecognized extinct lineage within that clade.

\section{Depositional Environment}

The Cucullaea I Allomember of the La Meseta Formation is interpreted to have been deposited in a nearshore marine to estuarine depositional system based on sedimentological criteria and the presence of various environmentally diagnostic invertebrate (Stilwell and Zinsmeister, 1992) and vertebrate (Reguero et al., 2012) fossils. Nevertheless, the presence of fossil seeds, wood, and sporadic terrestrial vertebrate bones and teeth attest to a significant contribution of continental material to the depositional environment.

The majority of extant earthworms and leeches occupy moist-terrestrial and freshwater settings, although some are known from marine environments (Lévêque et al., 2005). Branchiobdelids are obligate commensal symbionts on freshwater-crayfish hosts (Lee et al., 2009). On this basis, we consider that the producers of the La Meseta Formation cocoons were probably part of the biota living on the adjacent Antarctic Peninsula magmatic arc, and that the cocoons were transported by fluvial processes into nearshore marine settings of the back-arc basin. These are the first examples of clitellate annelid cocoons recovered from unequivocal marine strata; previous examples have been almost invariably recovered from plantrich fluvial floodbasin and levee facies (Manum et al., 1991; McLoughlin et al., 2002, 2014; Tosolini et al., 2002; Tosolini and Pole, 2010; Steinthorsdottir et al., 2015). Their occurrence as relatively complete and weakly compressed specimens (in most cases lacking only the detachable operculum) in marine strata reflects their durability to transport and resistance to burial diagenesis. Their resilience and ability to be transported between major environments indicate that clitellate cocoons might be useful for correlation between continental and shallow marine successions once comprehensive systematic surveys provide a better understanding of the diversity and stratigraphic ranges within the group.

The fossil record of clitellate cocoons extends back to at least the Middle Triassic (Vigran et al., 2014), but a comprehensive survey of mesofossils from a Middle Permian peat by Slater et al. (2012) found no evidence of annelid egg casings in an otherwise suitable host deposit, and such remains have not been forthcoming from palynological studies of other Palaeozoic strata. The occurrence and, thus, the stratigraphic and palaeoenvironmental application of these mesofossils is, therefore, likely to be restricted to post-Palaeozoic strata.

These are the first clitellate annelid cocoons recorded from the Cenozoic of Antarctica-only Triassic forms have been described previously (Bomfleur et al., 2012). Of the two most favoured groups to have produced these fossil cocoons, branchiobdellids live in commensal symbiosis with their crayfish hosts, feeding on detritus and epibionts (Lee et al., 2009), whereas hirudineans are predators or obligate parasites on a broad range of terrestrial and aquatic hosts (Sket and Trontelj, 2008). No parasitic or commensal associations have been described previously from the Paleogene continental biotas of the Antarctic Peninsula. However, a broad range of herbivorous, detritivorous, commensal, and parasitic interactions have been reported from older (Permian and Triassic), non-marine fossil assemblages in Antarctica (Klavins et al., 2005; Slater et al., 2012, 2013, 2015; Harper et al., 2013). The Seymour Island fossils provide an additional component to the trophic complexity identified in high-latitude terrestrial Antarctic ecosystems during the Paleogene.

Terrestrial ecosystems of Antarctica saw marked extinctions and decline in diversity from the middle Eocene onwards (Reguero et al., 2013), and were especially decimated by dramatic cooling at the end of the Eocene (Berggren and Prothero, 1992; Cantrill and Poole, 2012). The local lineages of Clitellata that produced the range of cocoons described here may have been casualties of that dramatic climatic transition, since the group is not represented in the modern Antarctic fauna. More extensive sampling will be required to ascertain the full history of non-marine annelids in Antarctica.

\section{CONCLUSIONS}

Three new species of fossil clitellate annelid cocoons attributed to two genera (one new) are described and illustrated. Based primarily on the anatomy of entombed spermatozoa, the fossil cocoons were probably produced by branchiobdellid annelids, although affinities with hirudineans (leeches) cannot be excluded entirely. If a branchiobdellid affinity is confirmed, this implies that crayfish worms had a much broader range in the Eocene compared to their modern (Northern Hemisphere) distribution. The new genus, Pegmatoth- 
ylakos, may represent a major extinct lineage within the Clitellata based on its unique cocoon wall architecture. Synchrotron-radiation-based Xray tomographic microscopy provides evidence of distorted hirudoin threads lining the walls of blind tubes within the alytine layer of the Burejospermum seymourense cocoon supporting an earlier hypothesis that such tubular cavities were produced by retraction of setae or some other anchoring appendage during the final stages of cocoon secretion. These fossil cocoons provide the only evidence thus far of terrestrial or freshwater clitellate annelids in the Eocene of Antarctica. Further systematic surveys of this category of acid-resistant mesofossils will undoubtedly provide a clearer understanding of the evolutionary history of clitellate annelids in Antarctica and, given their preservation in a range of depositional settings, they constitute a potential tool for correlation between continental and shallow-marine sedimentary successions. The presence of spermatozoal, bacterial, and vermiform inclusions in the walls of several clitellate annelid cocoons suggests that these fossils offer an exceptional resource for investigating the evolutionary history of soft-bodied micro-organisms of soil and aquatic environments.

\section{ACKNOWLEDGEMENTS}

We dedicate this paper to Professor $\mathrm{S}$. Manum (deceased September 30, 2015) who pioneered work on fossil clitellate annelid cocoons. MR and TM are indebted to the Argentine Antarctic Institute (IAA-DNA) and to the Argentine Air Force, which provided logistical support for fieldwork on Seymour Island. TM thanks the Swedish Polar Research Secretariat (SPFS) for logistical support. We thank M. de los Reyes (Museo de La Plata) for screening and picking samples, E.M. Friis (Swedish Museum of Natural History), F. Marone and M. Stampanoni (Villigen) for providing access to, and assistance with, synchrotron imaging with the Tomcat Beamline at the Swiss Light Source, P. Scherrer Institute. We thank J. Bouchal and J. Cunningham (Swedish Museum of Natural History) for assistance with SEM analyses and computed tomography using the Avizo software, respectively. V. Belivanova kindly segmented the tomographic images for Supplementary Animation 4. Financial support from the Swedish Research Council (VR grants 2014-5234 to S.M., 2014-5232 to B.B., and 2009-4447 to T.M.), the Wenner-Gren Foundation (guest researcher fellowship to B.B.), the Consejo Nacional de Investigaciones Científicas y Técnicas
(CONICET grant PIP 0462 to M.A.R.), and the Argentine National Agency for Promotion of Science and Technology (ANPCyT grant PICTO2010-0093 to M.A.R.) is gratefully acknowledged. We thank two anonymous reviewers and the editors for their constructive comments.

\section{REFERENCES}

Apakupakul, K., Siddall, M.E., and Burreson, E.M. 1999. Higher level relationships of leeches (Annelida : Clitellata: Euhirudinea) based on morphology and gene sequences. Molecular Phylogenetics and Evolution, 12:350-359.

Baldoni, A.M. and Taylor, T.N. 1985. Megasporas cretácicas de la Formación Springhill en el subsuelo de Argentina y Chile Austral. Ameghiniana, 21:151-167. (In Spanish)

Bargo, M.S. and Reguero, M.A. 1998. Annotated catalogue of the fossil vertebrates from Antarctica housed in the Museo de La Plata. I. Birds and land mammals from La Meseta Formation (Eocene-? early Oligocene), p. 211-221. In Casadio, S. (ed.), Paleógeno de América del Sur y de la Península Antártica, vol 5. Asociación Paleontológica Argentina, Publicación Especial, Buenos Aires.

Berggren, W.A. and Prothero, D.R. 1992. Eocene-Oligocene climatic and biotic evolution: an overview, p. 128. In Prothero, D.R. and Berggren W.A. (eds.), Eocene-Oligocene Climatic and Biotic Evolution. Princeton University Press, Princeton.

Bertling, M., Braddy, S.J., Bromley, R.G., Demathieu, G.R., Genise, J., Mikuláš, R., Nielsen, J.K., Nielsen, K.S.S., Rindsberg, A.K., Schlirf, M., and Uchman, A. 2006. Names for trace fossils: a uniform approach. Lethaia, 39:265-286.

Bhattacharjee, G. and Chaudhuri, P.S. 2002. Cocoon production, morphology, hatching pattern and fecundity in seven tropical earthworm species - a laboratory-based investigation. Journal of Biosciences, 27:283-294.

Bomfleur, B., Kerp, H., Taylor, T.N., Moestrup, Ø., and Taylor, E.L. 2012. Triassic leech cocoon from Antarctica contains fossil bell animal. Proceedings of the National Academy of Sciences of the United States of America, 109:20971-20974.

Bomfleur, B., Mörs, T., Ferraguti, M., Reguero, M.A., and McLoughlin, S. 2015. Fossilized spermatozoa preserved in a 50-myr-old annelid cocoon from Antarctica. Biology Letters, 11:20150431. doi:10.1098/rsbl.2015.0431

Bond, M., Kramarz, A., MacPhee, R., and Reguero, M. 2011. A new astrapothere (Mammalia, Meridiungulata) from La Meseta Formation, Seymour (Marambio) Island, and a reassessment of previous records of Antarctic astrapotheres. American Museum Novitates, 3718:1-16.

Bond, M., Pascual, R., Reguero, M.A., Santillana, S.N., and Marenssi, S.A. 1990. Los primeros ungulados 
extinguidos sudamericanos de la Antártida. Ameghiniana, 16:240. (in Spanish)

Brady, N.C. and Weil, R.R. 2009. Elements of the Nature and Properties of Soils (3rd Edition). Prentice Hall, Boston.

Cantrill, D.J. and Poole, I. 2012. The Vegetation of Antarctica through Geological Time. Cambridge University Press, Cambridge, UK.

Cardini, A. and Ferraguti, M. 2004. The phylogeny of Branchiobdellida (Annelida, Clitellata) assessed by sperm characters. Zoologischer Anzeiger, 243:37-46.

Chornogubsky, L., Goin, F.J., and Reguero, M.A. 2009. A reassessment of Antarctic polydolopid marsupials (Middle Eocene, La Meseta Formation). Antarctic Science, 21:285-297.

Coleman, J., Marotta, R., and Shain, D.H. 2008. Surface topology and structural integrity of the Theromyzon tessulatum (Annelida:Hirudinea:Glossiphoniidae) cocoon. Journal of Morphology, 269:812-819.

Conway Morris, S., Pickerill, R.K., and Harland, T.L. 1982. A possible annelid from the Trenton Limestone (Ordovician) of Quebec, with a review of fossil oligochaetes and other annulate worms. Canadian Journal of Earth Sciences, 19:2150-2157.

Del Valle, R.A., Elliot, D.H., and Macdonald, D.I.M. 1992. Sedimentary basins on the east flank of the Antarctic Peninsula: proposed nomenclature. Antarctic Science, 4:477-478.

Dimitriu, C., Sayers, C.W., Coleman, J., Shain, D.H. 2006. Two-dimensional ultrastructural elements lead to three-dimensional reconstruction of protuberances on the cocoon membrane of the leech, Theromyzon tessulatum. Tissue and Cell, 38:35-41.

Dingle, R. and Lavelle, M. 1998. Antarctic Peninsula cryosphere: early Oligocene (c. $30 \mathrm{Ma}$ ) initiation and a revised glacial chronology. Journal of the Geological Society of London, 155:433-437.

Donoghue, P.C.J., Bengtson, S., Dong, X., Gostling, N.J., Huldtgren, T., Cunningham, J.A., Yin, C., Yue, Z., Peng, F., and Stampanoni, M. 2006. Synchrotron X-ray tomographic microscopy of fossil embryos. Nature, 442:680-683.

Douglas, J.G. 1973. The Mesozoic floras of Victoria. Part 3. Memoirs of the Geological Survey of Victoria, 29:1-185.

Douglas, P.M.J., Affek, H.P., Ivany, L.C., Houben, A.J.P., Sijp, W.P., Sluijs, A., Schouten, S., and Pagani, M. 2014. Pronounced zonal heterogeneity in Eocene southern high-latitude sea surface temperatures. Proceedings of the National Academy of Sciences of the United States of America, 111:6582-6587.

Dunn, R. 2010. The beauty of insect eggs. National Geographic, 218(3):110-121.

Dutton, A.L., Lohmann, K., and Zinsmeister, W.J. 2002. Stable isotope and minor element proxies for Eocene climate of Seymour Island, Antarctica. Paleoceanography, 17:1-13.

Edwards, C.A. and Lofty, J.R. 1977. Biology of Earthworms. John Wiley and Sons, New York, NY.
Eiseman, C. and Charney, N. 2010. Tracks and Signs of Insects and Other Invertebrates: A Guide to North American Species. Stackpole Books, Mechanicsburg.

Elliot, D.H. 1988. Tectonic setting and evolution of the James Ross Basin, northern Antarctic Peninsula, p. 541-555. In Feldmann, R.M. and Woodburne, M.O. (eds.), Geology and Paleontology of Seymour Island, Antarctic Peninsula. Geological Society of America Memoir, 169, The Geological Society of America, Boulder, Colorado.

Elliot, D.H. and Trautman, T.A. 1982. Lower Tertiary strata on Seymour Island, Antarctic Peninsula, p. 287-297. In Craddock, C. (ed.), Antarctic Geoscience. University of Wisconsin Press, Madison.

Erséus, C. and Grimm, R. 2002. A new species of Ainudrilus (Tubificidae) from South Georgia, and other subantarctic freshwater oligochaetes. Hydrobiologia, 468:77-81

Erséus, C. and Källersjö, M. 2004. 18S rDNA phylogeny of Clitellata (Annelida). Zoologica Scripta, 33:187196. doi:10.1111/j.1463-6409.2004.00146.x

Evitt, W.R. 1963. A discussion and proposals concerning fossil dinoflagellates, hystrichospheres, and acritarchs. II. Proceedings of the National Academy of Sciences of the United States of America, 19:298302.

Ferraguti, M. and Erséus, C. 1999. Sperm types and their use for a phylogenetic analysis of aquatic clitellates. Hydrobiologia, 402:225-237. doi:10.1023/ A:1003752811830

Fisher, H.L. and Watson, J. 2015. A fossil insect egg on an Early Cretaceous conifer shoot from the Wealden of Germany. Cretaceous Research, 53:38-47.

Geasa, N.M.S.H. 2014. Observation of Branchiobdellidae (Clitellata, Annelida) on freshwater crayfish in British Columbia, Canada. Sci-Afric Journal of Scientific Issues, Research and Essays, 2:94-107.

Gelfo, J.N., Mörs, T., Lorente, M., López, G.M., and Reguero, M. 2015. The oldest mammals from Antarctica, early Eocene of the La Meseta Formation, Seymour Island. Palaeontology, 58:101-110.

Gelfo, J.N., Reguero, M.A., Lopez, G.M., Carlini, A.A., Ciancio, M.R., Chornogubsky, L., Bond, M., Goin, F.J., and Tejedor, M. 2009. Eocene mammals and continental strata from Patagonia and Antarctic Peninsula, p. 567-592. In Albright III, L.B. (ed.), Papers on Geology, Vertebrate Paleontology, and Biostratigraphy in Honor of Michael O. Woodburne. Museum of Northern Arizona Bulletin 64, Flagstaff, Arizona.

Genise, J.F. 2004. Ichnotaxonomy and ichnostratigraphy of chambered trace fossils in palaeosols attributed to coleopterans, ants and termites, p. 419-453. In Mcllroy, D. (ed.), The Application of Ichnology to Palaeoenvironmental and Stratigraphic Analysis. Geological Society of London Special Publications, 228. Geological Society of London, London.

Genise, J.F. and Bown, T.M. 1994. New Miocene scarabaeid and hymenopterous nests and Early Mio- 
cene (Santacrucian) palaeoenvironments, Patagonian Argentina. Ichnos, 3:107-117.

Gergens, F. 1861. Über fossile Blutegel-Coccons bei Mainz. Neues Jahrbuch für Mineralogie, Geognosie, Geologie und Petrefakten-Kunde, Abhandlungen, 1861:670-671. (in German)

Goin, F.J. and Carlini, A. 1995. An Early Tertiary microbiotheriid marsupial from Antarctica. Journal of Vertebrate Palaeontology, 15:205-207.

Goin, F.J., Reguero, M.A., Pascual, R., von Koenigswald, W., Woodburne, M.O., Case, J.A., Vieytes, C., Marenssi, S.A., and Vizcaíno, S.F. 2006. First gondwanatherian mammal from Antarctica, p. 135-144. In Francis, J.E., Pirrie, D., and Crame, J.A. (eds.), Cretaceous-Tertiary High-Latitude Palaeoenvironments, James Ross Basin, Antarctica. Geological Society of London, Special Publications, 258, London.

Gunther, P.R. and Hills, L.V. 1972. Megaspores and other palynomorphs of the Brazeau Formation (Upper Cretaceous), Nordegg area, Alberta. Geoscience and Man, 4:29-48.

Harper, C.J., Taylor, T.N., Krings, M., and Taylor, E.L. 2013. Mycorrhizal symbiosis in the Paleozoic seed fern Glossopteris from Antarctica. Review of Palaeobotany and Palynology, 192:22-31.

Harris, T. 1926. Note on a new method for the investigation of fossil plants. New Phytologist, 25:58.

Hathway, B. 2000. Continental rift to back-arc basin: Jurassic-Cretaceous stratigraphical and structural evolution of the Larsen Basin, Antarctic Peninsula. Journal of the Geological Society of London, 157:417-432.

Heřmanová, Z. and Kvaček, J. 2010. Late Cretaceous Palaeoaldrovanda, not seeds of a carnivorous plant, but eggs of an insect. Journal of the National Museum (Prague), Natural History Series, 179(9):105-118.

Heřmanová, Z., Bodor, E., and Kvaček, J. 2013. Knoblochia cretacea, Late Cretaceous insect eggs from Central Europe. Cretaceous Research, 45:7-15.

Hinton, H.E. 1970. Insect eggshells. Scientific American, 223:84-91.

Hinton, H.E. 1981. Biology of Insect Eggs. Pergamon Press, Oxford.

Holland, M. 2010. Naturally Curious: A photographic Field Guide and Month-by-Month Journey through the Fields, Woods, and Marshes of New England. Trafalgar Square Books, North Pomfret.

Horst, U. 1954. Merkwürdige Gebilde in Kohlen aus dem Wealden. Geologie, 3:610-616. (In German)

Hueber, F.M. 1982. Megaspores and a palynomorph from the Lower Potomac Group in Virginia. Smithsonian Contributions to Paleobiology, 49:1-69.

Hughes, N.F. 1955. Wealden plant microfossils. Geological Magazine, 93:201-217.

Humphreys, G.S. 2003. Evolution of terrestrial burrowing invertebrates, p. 211-215. In Roach, I.C. (ed.), Advances in Regolith. CRC LEME, Canberra.
Ivany, L.C., Lohmann, K.C., Hasiuk, F., Blake, D.B., Glass, A., Aronson, R.B., and Moody, R.M. 2008. Eocene climate record of a high southern latitude continental shelf: Seymour Island, Antarctica. Geological Society of America Bulletin, 120:659-678.

Jamieson, B.G.M. and Rouse, G.W. 1989. The spermatozoa of the Polychaeta (Annelida): an ultrastructural review. Biological Reviews, 64:93-157.

Jansson, I.-M., McLoughlin, S., and Vajda, V. 2008. Early Jurassic annelid cocoons from eastern Australia. Alcheringa, 32:285-296.

Klavins, S.D., Kellogg, D.W., Krings, M., Taylor, E.L., and Taylor, T.N. 2005. Coprolites in a Middle Triassic cycad pollen cone: evidence for insect pollination in early cycads? Evolutionary Ecology Research, 7:479-488.

Kovach, W.L. and Dilcher, D.L. 1988. Megaspores and other dispersed plant remains from the Dakota Formation (Cenomanian) of Kansas, USA. Palynology, 12:89-119.

Kozur, H. 1970. Fossile Hirudinea aus dem Oberjura von Bayern. Lethaia, 3:225-232. (In German)

Krassilov, V.A. 1972. Mesozoiskaya flora reki Burei (Ginkgoales i Czekanowskiales). [The Mesozoic flora of the Bureja Region (Ginkgoales and Czekanowskiales)]. Akademii Nauka SSSR, Moscow. (in Russian)

Kutschera, U. and Epshtein, V.M. 2006. Nikolaj A. Livanow (1876 - 1974) and the living relict Acanthobdella peledina (Annelida, Clitellata). Annals of the History and Philosophy of Biology, 11:85-98.

Lamarck, J.B. 1809. Philosophie Zoologique. Chez Dentu, Paris. (In French)

LaPasha, C.A. and Miller, C.M. Jr. 1985. Flora of the Early Cretaceous Kootenai Formation in Montana: bryophytes and tracheophytes excluding conifers. Palaeontographica B, 196:111-145.

Lee, J.H., Kim, T.W., and Choe, J.C. 2009. Commensalism or mutualism: conditional outcomes in a branchiobdellid-crayfish symbiosis. Oecologia, 159:217224.

Lévêque, C., Balian, E.V., and Martens, K. 2005. An assessment of animal species diversity in continental waters, p. 39-67. In Segers, H. and Martens, K. (eds.), Aquatic Biodiversity II. The Diversity of Aquatic Ecosystems (Developments in Hydrobiology). Springer, Dordrecht.

Manum, S.B. 1996. Clitellate cocoons, p. 361-364. In Jansonius, J. and McGregor, D.C. (eds.), Palynology: Principles and Applications, Volume 1. American Association of Stratigraphic Palynologists Foundation, College Station, Texas.

Manum, S.B., Bose, M.N., and Sawyer, R.T. 1991. Clitellate cocoons in freshwater deposits since the Triassic. Zoologica Scripta, 20:347-366.

Manum, S.B., Bose, M.N., Sawyer, R.T., and Boström, S. 1994. A nematode (Captivonema cretacea gen. et sp. n.) preserved in a clitellate cocoon wall from the Early Cretaceous. Zoologica Scripta, 23:27-31. 
Marenssi, S.A. 2006. Eustatically-controlled sedimentation recorded by Eocene strata of the James Ross Basin, Antarctica, p. 125-133. In Francis, J.E., Pirrie, D., and Crame, J.A. (eds.), Cretaceous-Tertiary High-latitude Palaeoenvironments, James Ross Basin, Antarctica. Geological Society of London, Special Publications, 258, Geological Society of London, London.

Marenssi, S.A., Net, L.I., and Santillana, S.N. 2002. Provenance, depositional and paleogeographic controls on sandstone composition in an incised valley system: the Eocene La Meseta Formation, Seymour Island Antarctica. Sedimentary Geology, 150:301321.

Marenssi, S.A., Santillana, S.N., and Rinaldi, C.A. 1998. Stratigraphy of the La Meseta Formation (Eocene), Marambio (Seymour) Island, Antarctica, p. 137-146. In Casadio, S. (ed.), Paleógeno de América del Sur y de la Península Antártica. Asociación Paleontológica Argentina, Publicación Especial, 5, Buenos Aires.

Marotta, R., and Ferraguti, M. 2009. Sperm ultrastructure in assessing phylogenetic relationships among clitellate annelids, p. 314-327. In Shain, D.H. (eds.), Annelids in Modern Biology. John Wiley and Sons, Hoboken, NJ.

Marotta, R., Ferraguti, M., Erséus, C., Gustavsson, L.M. 2008. Combined-data phylogenetics and character evolution of Clitellata (Annelida) using 18S rDNA and morphology. Zoological Journal of the Linnean Society, 154:1-26.

Martin, P. 2001. On the origin of the Hirudinea and the demise of the Oligochaeta. Proceedings of the Royal Society of London B, 268:1089-1098.

Martin, P., Martinez-Ansemil, E., Pinder, A., Timm, T., and Wetzel, M.J. 2008. Global diversity of oligochaetous clitellates ("Oligochaeta"; Clitellata) in freshwater. Hydrobiologia, 595:117-127. doi:10.1007/s10750007-9009-1

Mason, T.A., Mcllroy, J.P., and Shain, D.H. 2004. A cysteine-rich protein in the Theromyzon (Annelida: Hirudinea) cocoon membrane. FEBS Letters, 561:167-172.

Matzke-Karasz, R., Neil, J.V., Smith, R.J., Symonová, R., Mořkovský, L., Archer, M., Hand, S.J., Cloetens, P., and Tafforeau, P. 2014. Subcellular preservation in giant ostracod sperm from an early Miocene cave deposit in Australia. Proceedings of the Royal Society $B, 281: 20140394$. doi:10.1098/rspb.2014.0394

McLoughlin, S., Haig, D.W., Backhouse, J, Holmes, M.A., Ellis, G., Long, J.A., and McNamara, K.J. 1995. Oldest Cretaceous sequence, Giralia Anticline, Carnarvon Basin, Western Australia: late HauterivianBarremian. AGSO Journal of Australian Geology and Geophysics, 15:445-468.

McLoughlin, S., Jansson, I.-M., and Vajda, V. 2014. Megaspore and microfossil assemblages reveal diverse herbaceous lycophytes in the Australian Early Jurassic flora. Grana, 53:22-53.
McLoughlin, S., Tosolini, A.-M., Nagalingum, N., and Drinnan, A.N. 2002. The Early Cretaceous (Neocomian) flora and fauna of the lower Strzelecki Group, Gippsland Basin, Victoria, Australia. Association of Australasian Palaeontologists Memoirs, 26:1-144.

Melchior, R.C. and Hall, J.W. 1983. Some megaspores and other small fossils from the Wannagan Creek site (Paleocene), North Dakota. Palynology, 7:133145.

Michael, F. 1936. Paläobotanische und Kohlenpetrographische Studien in der Nordwestdeutschen Wealden Formation. Abhandlungen der Preussischen Geologischen Landesanstalt (N.F.), 166:1-79. (In German)

Michaelsen, W. 1919. Über die Beziehungen der Hirudineen zu den Oligochäten. Mitteilungen aus dem Naturhistorischen Museum, Hamburg, 36:131153. (In German)

Mikulic, D.G., Briggs, D.E.G., and Kluessendorf, J. 1985. A Silurian soft-bodied biota. Science, 228:715-717.

Montes, M., Nozal, F., Santillana, S., Marenssi, S., and Olivero, E. 2013. Mapa Geológico de la Isla Marambio (Seymour) Escala 1:20.000 Primera Edición. Serie Cartográfica Geocientífica Antártica. Instituto Geológico y Minero de España, Madrid, and Instituto Antártico Argentino, Buenos Aires. (In Spanish)

Novo, M., Almodóvar, A., Fernández, R., Giribet, G., and Díaz Cosín, D.J. 2011. Understanding the biogeography of a group of earthworms in the Mediterranean basin-The phylogenetic puzzle of Hormogastridae (Clitellata: Oligochaeta). Molecular Phylogenetics and Evolution, 61:125-135.

Parry, L., Tanner, A., and Vinther, J. 2014. The origin of annelids. Palaeontology 57, 1091-1103.

Poinar, G. 2000. First fossil record of stalked spermatophores with sperm (Collembola: Hexapoda). Historical Biology, 14:229-234. doi:10.1080/10292380009380570

Pott, C., Labandeira, C.C., Krings, M., and Kerp, H. 2008. Fossil insect eggs and ovipositional damage on bennettitalean leaf cuticles from the Carnian (Upper Triassic) of Austria. Journal of Paleontology 82, 778-789.

Quaglio, F., Morolli, C., Galuppi, R., Bonoli, C., Marcer, F., Nobile, L., De Luise, G., and Tampieri, M.P. 2006. Preliminary investigations of disease-causing organisms in the white-clawed crayfish Austropotamobius pallipes complex from streams of northern Italy. Bulletin Francais de la Peche et de la Pisciculture, 380381:1271-1290.

Raven, P.H., Evert, R.F., and Eichhorn, S.E. 1986. Biology of Plants. Worth Publishers Inc., New York.

Reguero, M., Goin, F., Acosta Hospitaleche, C., Marenssi, S., and Dutra, T. 2013. The terrestrial biotic dimension of West Antarctica, p. 55-110. In Reguero, M., Goin, F., Acosta Hospitaleche, C., Dutra, T., and Marenssi, S. (eds.), Late Cretaceous/ Paleogene West Antarctica Terrestrial Biota and its Intercontinental Affinities. Springer, Dordrecht. 
Reguero, M.A., Marenssi, S.A., and Santillana, S.N. 2002. Antarctic Peninsula and Patagonia Paleogene terrestrial environments: biotic and biogeographic relationships. Palaeogeography, Palaeoclimatology, Palaeoecology, 179:189-210.

Reguero, M.A., Marenssi, S.A., and Santillana, S.N. 2012. Weddellian marine/coastal vertebrates diversity from a basal horizon (Ypresian, Eocene) of the Cucullaea I Allomember, La Meseta Formation, Seymour (Marambio) Island, Antarctica. Revista Peruana de Biología, 19:275-284.

Ren, S.-Z. 1992. An Iconography of Hemiptera-Heteroptera Eggs in China. Science Publishing Company, Beijing. (In Chinese)

Robertson, J., Gomersall, M., and Gill, P. 1975. Mycoplasma hominis: growth, reproduction, and isolation of small viable cells. Journal of Bacteriology, 124:1007-1018.

Rodriguez, P. and Rico, E. 2008. A new freshwater oligochaete species (Clitellata: Enchytraeidae) from Livingston Island, Antarctica. Polar Biology, 31:12671279

Rossi, A.M., Saidel, W.M., Marotta, R., Saglam, N., and Shain, D.H. 2013. Operculum ultrastructure in leech cocoons. Journal of Morphology, 274:940-946.

Rousset, V., Pleijel, F., Rouse, G.W., Erséus, C., Siddall, M.E. 2007. A molecular phylogeny of annelids. Cladistics, 23:41-63.

Sadler, P. 1988. Geometry and stratification of uppermost Cretaceous and Paleogene units of Seymour Island, northern Antarctic Peninsula. Geological Society of America, Memoir, 169:303-320.

Savrda, C.E. 1991. Teredolites, wood substrates, and sea-level dynamics. Geology, 19:905-908.

Sawyer, R.T. 1986. Leech Biology and Behaviour I-III. Clarendon Press, Oxford.

Sayers, C.W., Coleman, J., and Shain, D.H. 2009. Cell dynamics during cocoon secretion in the aquatic leech, Theromyzon tessulatum (Annelida: Clitellata: Glossiphoniidae). Tissue and Cell, 41:35-42.

Schulz, H.N. and Jorgensen, B.B. 2001. "Big bacteria". Annual Review of Microbiology, 55:105-137.

Schwarzhans, W., Mörs, T., Engelbrecht, A., Reguero, M., and Kriwet, J. in press. Before the freeze: Otoliths from the Eocene of Seymour Island, Antarctica, reveal dominance of gadiform fishes (Teleostei). Journal of Systematic Palaeontology, doi/full/10.1080/14772019.2016.1151958

Seilacher, A. 2007. Trace Fossil Analysis. Springer, Berlin.

Siddall, M.E., Apakupakul, K., Burreson, E.M., Coates, K.A., Erséus, C., Gelder, S.R., Källersjö, M., TrapidoRosenthal, H. 2001. Validating Livanow: molecular data agree that leeches, branchiobdellidans, and Acanthobdella peledina form a monophyletic group of Oligochaetes. Molecular Phylogenetics and Evolution, 21:346-351.
Singh, C. 1964. Microflora of the Lower Cretaceous Mannville Group, east-central Alberta. Research Council of Alberta Bulletin, 15:1-239.

Sket, B. and Trontelj, P. 2008. Global diversity of leeches (Hirudinea) in freshwater. Hydrobiologia, 595:129137.

Slater, B.J., McLoughlin, S., and Hilton, J. 2012. Animalplant interactions in a Middle Permian permineralised peat of the Bainmedart Coal Measures, Prince Charles Mountains, Antarctica. Palaeogeography, Palaeoclimatology, Palaeoecology, 363-364:109126.

Slater, B.J., McLoughlin, S., and Hilton, J. 2013. Peronosporomycetes (Oomycota) from a Middle Permian permineralised peat within the Bainmedart Coal Measures, Prince Charles Mountains, Antarctica. PLoS ONE, 8(8):e70707. doi:10.1371/journal.pone.0070707

Slater, B.J., McLoughlin, S., and Hilton, J. 2015. A highlatitude Gondwanan lagerstätte: The Permian permineralised peat biota of the Prince Charles Mountains, Antarctica. Gondwana Research, 27:14461473.

Smith, D.J. 2001. Pennack's Freshwater Invertebrates of the United States: Porifera to Crustacea, 4th Edition. John Wiley and Sons, New York.

Sourakov, A. and Emmel, T.C. 1995. Life history of Greta diaphana from the Dominican Republic (Lepidoptera: Nymphalidae). Tropical Lepidoptera, 6:155-157.

Steinthorsdottir, M., Tosolini, A.-M.P., and McElwain, J.C. 2015. Evidence for insect and annelid activity across the Triassic-Jurassic transition of east Greenland. Palaios, 30:597-607.

Stilwell, J.D. and Zinsmeister, W.J. 1992. Molluscan systematics and biostratigraphy: Lower Tertiary La Meseta Formation, Seymour Island, Antarctic Peninsula. Antarctic Research Series, 55:1-152.

Struck, T.H., Paul, C., Hill, N., Hartmann, S., Hösel, C., Kube, M., Lieb, B., Meyer, A., Tiedemann, R., Purschke, G., and Bleidorn, C. 2011. Phylogenomic analyses unravel annelid evolution. Nature, 471:95-98.

Tejedor, M.F., Goin, F.J., Gelfo, J.N., López, G.M., Bond, M., Carlini, A.A., Scillato-Yan, G.J., Woodburne, M.O., Chornogubsky, L., Aragón, E., Reguero, M.A., Czaplewski, N.J., Vincon, S., Martin, G.M., and Ciancio, M.R. 2009. New early Eocene mammalian fauna from western Patagonia, Argentina. American Museum Novitates, 3638:1-43.

Tosolini, A.-M.P., McLoughlin, S., and Drinnan, A.N. 2002. Early Cretaceous megaspore assemblages from southeastern Australia. Cretaceous Research, 23:807-844.

Tosolini, A.-M.P. and Pole, M. 2010. Insect and clitellate annelid traces in mesofossil assemblages from the Cretaceous of Australasia. Alcheringa, 34:397-419.

Vávra, J. and Larsson, J.I.R. 2014. Structure of Microsporidia, p. 1-70. In Weiss, L.M. and Becnel, J.J. (eds.), Microsporidia Pathogens of Opportunity. Wiley Blackwell, Ames, lowa. 
Vigran, J.O., Mangerud, G., Mørk, A., Worsley, D., and Hochuli, P.A. 2014. Palynology and Geology of the Triassic Succession of Svalbard and the Barents Sea. Geological Survey of Norway Special Publication 14. Norges geologiske undersøkelse, Trondheim.

Weigert, A., Helm, C., Meyer, M., Nickel, B., Arendt, D., Hausdorf, B., Santos, S.R., Halanych, K.M., Purschke, G., Bleidorn, C., and Struck, T.H. 2014. Illuminating the base of the annelid tree using transcriptomics. Molecular Biology and Evolution, 31:1391-1401.
Wills, M.A. 1993. Annelida, p. 271-278. In Benton, M.J. (ed.), The Fossil Record II. Chapman and Hall, London.

Wolf, K.W. and Reid, W. 2001. Egg morphology and hatching in Mormidea pictiventris (Hemiptera: Pentatomidae). Canadian Journal of Entomology, 79:726-736.

Woodburne, M.O. and Zinsmeister, W.J. 1984. The first land mammal from Antarctica and its biogeographic implications. Journal of Paleontology, 54:913-948.

Zick, K. 1933. Weiteres über Zucht und Fortpflanzung des Medizinischen Blutegels. Zoologischer Anzeiger, 103:49-55. (In German) 


\section{SUPPLEMENTARY ANIMATIONS}

SUPPLEMENTARY ANIMATION 1. Animation (.mov format; $24 \mathrm{sec}$ ) compiled using Avizo software showing the rotation of an isosurface rendering of a Burejospermum seymourense cocoonwall fragment (NRMS089729) generated from Synchrotron-radiation-based X-Ray tomographic microscopy (SRXTM) at the TOMCAT beamline of the Swiss Light Source at the Paul Scherrer Institute, Switzerland, using a beam energy of $10 \mathrm{kV}$ and a $20 \times$ objective. Note the relatively smooth (inner) alytine and filamentous (outer) hapsine with embedded mineral matter. palaeo-electronica.org/content/20161448-eocene-annelid-cocoons

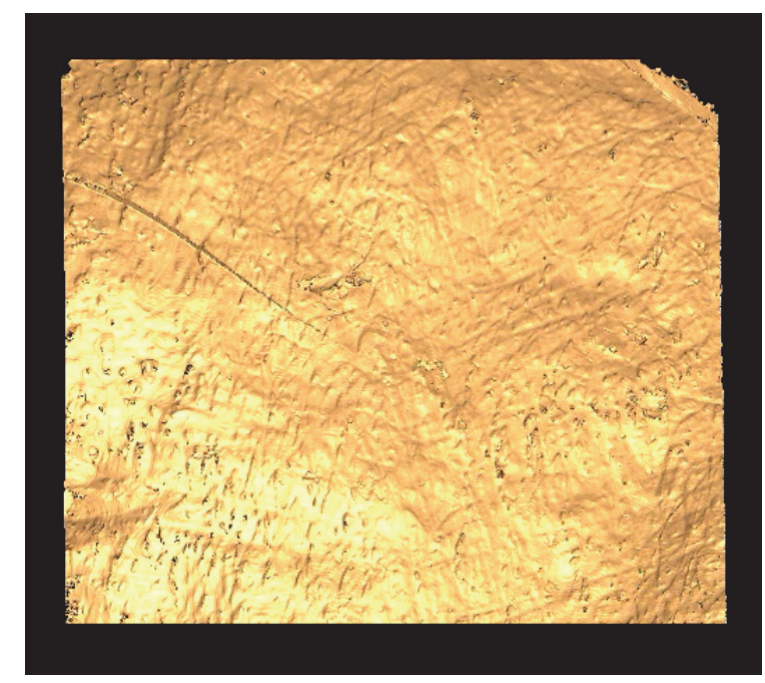

SUPPLEMENTARY ANIMATION 2. Animation (.mov format; $24 \mathrm{sec}$ ) compiled using Avizo software showing the rotation of a volume rendering of a Burejospermum seymourense cocoon wall fragment (NRMS089729) generated from Synchrotron-radiation-based X-ray tomographic microscopy (SRXTM) at the TOMCAT beamline of the Swiss Light Source at the Paul Scherrer Institute, Switzerland, using a beam energy of $10 \mathrm{kV}$ and a $20 \times$ objective. Note the irregular distribution of entombed mineral matter (white) and the hollow tube in the lower portion of the wall fragment that may represent the original position of a withdrawn seta.

palaeo-electronica.org/content/2016/1448-eocene-annelid-cocoons

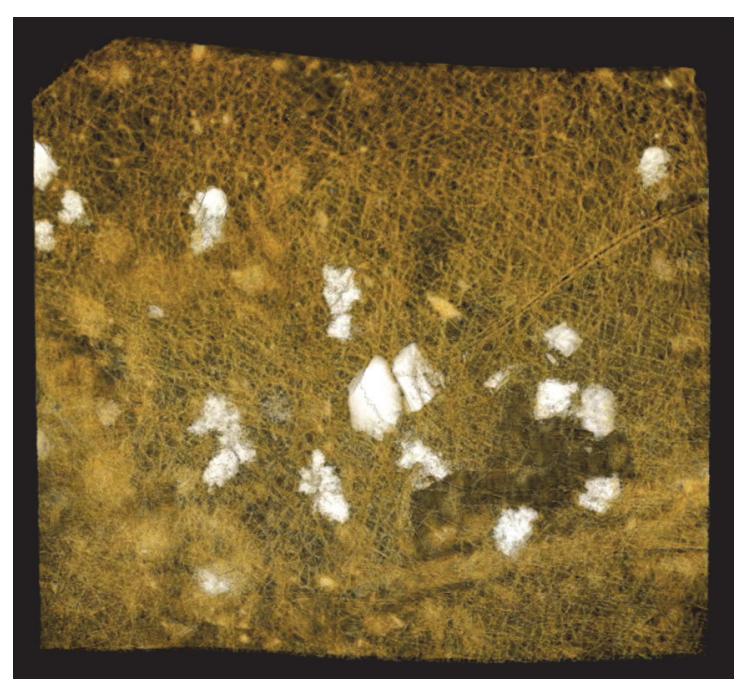


SUPPLEMENTARY ANIMATION 3. Composite orthoslice animation (.mov format; $24 \mathrm{sec}$ ) of 1461 steps through a Burejospermum seymourense cocoon wall fragment (NRMS089729) using Avizo software. Orthoslice data obtained via synchrotron-radiation-based X-ray tomographic microscopy at the TOMCAT beamline of the Swiss Light Source at the Paul Scherrer Institute, Switzerland, using a beam energy of $10 \mathrm{kV}$ and a $20 \times$ objective. Note the similar composition of the dense (inner) alytine and filamentous (outer) hapsine; the hollow pseudo-segmented tube in the lower left portion parallel to the cocoon surface may represent the original position of a withdrawn seta; some smaller cavities in the alytine represent moulds of encased spermatozoa and micro-organisms.

palaeo-electronica.org/content/2016/1448-eocene-annelid-cocoons

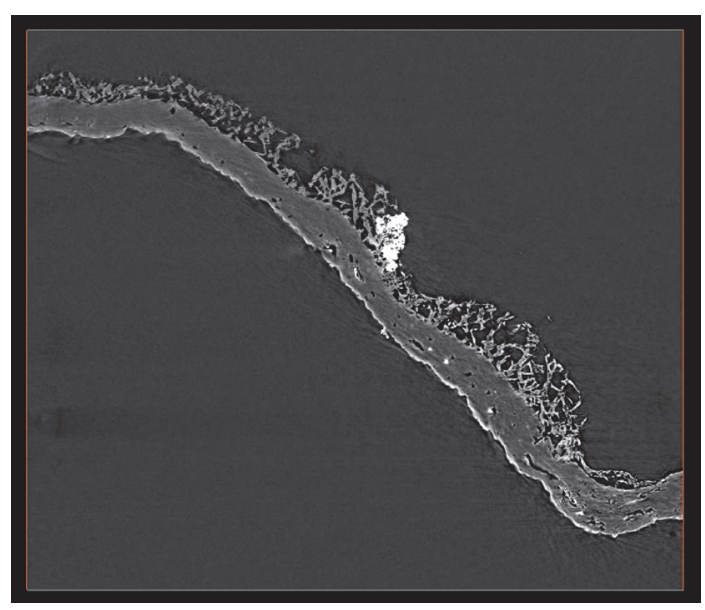

SUPPLEMENTARY ANIMATION 4. Animation of a three-dimensional volume rendering (.mov format; $24 \mathrm{sec}$ ) of a Burejospermum seymourense cocoon wall fragment (NRMS089729) compiled from segmented computed tomographic data to illustrate an enclosed tubular structure (possible setal anchoring trace) highlighted in yellow that is flared at one end and tapers distally. palaeo-electronica.org/content/2016/1448-eocene-annelid-cocoons

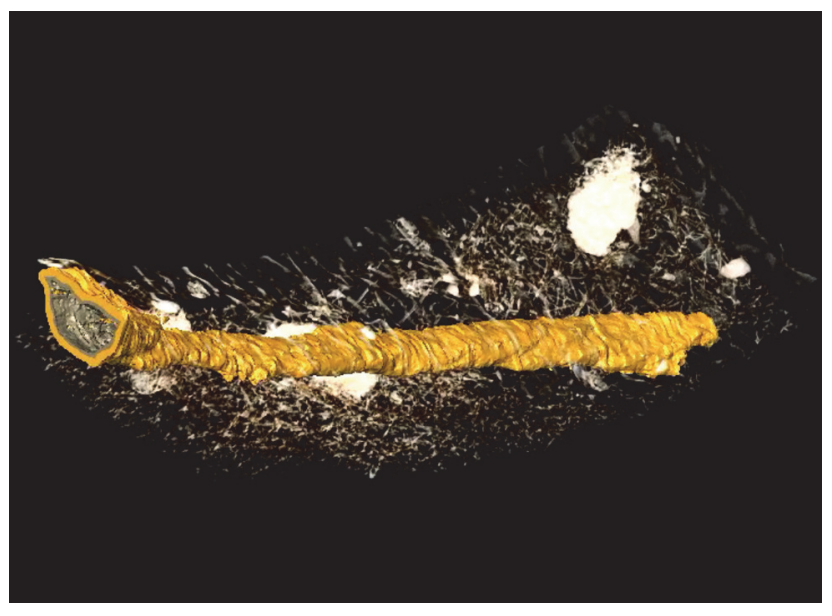

